\title{
Soil hydrothermal modeling in a dry alpine agricultural zone: The effect of soil airflow
}

\author{
Jiaxin Wang ${ }^{\mathrm{a}, \mathrm{c}}$, Xiaodong Gao ${ }^{\mathrm{a}, \mathrm{b}, \mathrm{c}, \text {, }}$, Xining Zhao ${ }^{\mathrm{a}, \mathrm{b}, \mathrm{c}}$, Hua Wan ${ }^{\mathrm{a}, \mathrm{c}}$, Yijian Zeng ${ }^{\mathrm{d}}$, Lianyu Yu ${ }^{\mathrm{d}}$, \\ Brett Robinson $^{\mathrm{e}}$, Yanqing Zhou ${ }^{\mathrm{a}, \mathrm{c}}$, Kadambot H.M. Siddique ${ }^{\mathrm{f}}$, Pute $\mathrm{Wu}^{\mathrm{a}, \mathrm{c}}$ \\ ${ }^{a}$ College of Water Resources and Architectural Engineering, Northwest A\&F University, Yangling 712100, China \\ ${ }^{\mathrm{b}}$ Institute of Soil and Water Conservation, Northwest A\&F University, Yangling 712100, China \\ ${ }^{\mathrm{c}}$ Institute of Water-saving Agriculture in Arid Areas of China, Northwest A\&F University, Yangling 712100, China \\ ${ }^{\mathrm{d}}$ Faculty of Geo-information and Earth Observation (ITC), University of Twente, Enschede, Netherlands \\ ${ }^{\mathrm{e}}$ Department of Soil and Physical Sciences, Lincoln University, Lincoln 7647, Christchurch, New Zealand \\ ${ }^{\mathrm{f}}$ The UWA Institute of Agriculture, The University of Western Australia, Crawley WA 6009, Australia
}

\section{A R T I C L E I N F O}

Handling Editor: Morgan Cristine

\section{Keywords:}

Hydrothermal dynamics

Soil airflow

Arid agricultural region

Tibetan Plateau

\begin{abstract}
A B S T R A C T
Acquiring soil hydrothermal information using process-based models is important for agricultural management in dry alpine regions where in situ data collection is difficult. However, few modeling studies have considered the soil airflow transport mechanism for arid regions especially, the presence of dry airflow in soil can affect water and heat transport. Here, we adopt an airflow-coupling hydrological model, Simultaneous Transfer of Energy, Mass, and Momentum in Unsaturated Soil (STEMMUS), to simulate soil hydrothermal processes and evapotranspiration dynamics in a dry farmland on the Tibetan Plateau (TP). The effect of airflow on the simulations was carefully assessed. Our results suggested that STEMMUS can reliably capture daily observations-the average values for the index of agreement $(d)$ in the $20-100 \mathrm{~cm}$ soil profile were 0.94 for soil temperature, 0.83 for soil moisture, 0.72 for soil evaporation and 0.83 for crop evapotranspiration, respectively, during the validation period. The impacts of considering airflow transport occurred when water inputs reached $22.8 \mathrm{~mm}$, showing a positive relationship with increasing precipitation/irrigation. Incorporating airflow in the model showed minor differences but basically improved the modeling precision for soil moisture (reduction in root mean squared error (RMSE) values ranging from 0 to 95.9\%), evapotranspiration (reduction in RMSE values ranging from 0 to $97.8 \%$ ) and evaporation (reduction in RMSE values ranging from 0 to $99.3 \%$ ) following rainfall/irrigation events. These findings provide sights into the role of airflow in the complex soil physical processes, and highlight that rainfall/irrigation inputs are a major factor affecting simulations when airflow is considered.
\end{abstract}

\section{Introduction}

The Tibetan Plateau (TP), also known as the third pole of the earth (Qiu, 2008), plays a principal role in Asian hydrological cycles (Pan et al., 2018; Ding et al., 2019). In past decades, the subsistence of TP inhabitants has largely relied on farming and animal husbandry. However, due to extensive grassland degradation reported on the TP (Harris, 2010; Yao et al., 2016; Liu et al., 2018a; Liu et al., 2018b; Ren et al., 2019), which was partly caused by overgrazing (Miehe et al., 2019), a need to promote alpine agriculture has been prioritized to enable development while avoiding ecological deterioration (Zhang et al.,
2013; d'Alpoim Guedes et al., 2013; d'Alpoim Guedes et al., 2015; d'Alpoim Guedes, 2018; Wang et al., 2020). Nevertheless, a major problem is that part of the agricultural land on the TP is located in arid and semiarid zones, where soil water availability and soil temperature are key variables controlling agricultural productivity (Wang et al., 2020). Understanding spatiotemporal variation of these fundamental hydrothermal properties (i.e., soil moisture, soil temperature and evapotranspiration) plays an important role in ensuring local agricultural productivity.

Modeling can be a better choice over in situ observations for understanding soil hydrothermal dynamics in the TP agricultural regions,

\footnotetext{
* Corresponding author at: Institute of Soil and Water Conservation, Northwest A\&F University, Yangling 712100, China.

E-mail address: gao_xiaodong@nwafu.edu.cn (X. Gao).
} 
considering the high costs of equipment transportation and labor and the high risk of decreased oxygen in the air. Models of relevant processes are generally established based on validated physical equations, such as Richards' equation (de Rooij, 2010), which has been applied commonly to describe soil water flow transport (Massari et al., 2014; Weber et al., 2017; Ahmad et al., 2018; Liu et al., 2018; Hu et al., 2019; Sadeghi et al., 2019), and many models now popularly used are developed based on this equation, such as the HYDRUS model (Šimůnek and van Genuchten, 2008) and Simultaneous Heat and Water (SHAW) model (Flerchinger and Saxton, 1989). So far, sophisticated characteristics have been incorporated into these models, for examples, crop water use, soil layer features, or surface coverage (Hou et al., 2018; Di Prima et al., 2019; Kacimov et al., 2019; Kader et al., 2019). However, although several studies had endeavored to explain the necessity of airflow in soil moisture modeling (Schrefler and Zhan, 1993; Parlange et al., 1998; Zeng et al., 2011a), little attention has been paid to the effect of soil dry airflow on modeling results.

The impact of airflow induced by atmospheric pressure variation on soil - atmosphere gas exchange has been a topic of discussion since Buckingham (1904) described air movement in soil in response to atmospheric pressure. This might be particularly important in arid regions because soil gas fluxes (vapor/dry air) account for a relatively higher proportion of soil porosity than liquid water flow in the vadose (unsaturated) zone, and previous studies have suggested that soil vapor transport is partly driven by the soil - air pressure gradient (Olivella and Gens 2000; Zeng et al., 2011a). Numerous experiments have shown that vapor flow plays an important role in mass and energy transfers in dry soils (Milly, 1982; Scanlon and Milly, 1994; Cahill and Parlange, 1998; Grifoll et al., 2005; Saito et al., 2006; Bittelli et al., 2008; Zeng et al., 2009, 2011a; Zeng et al., 2011b; Garcia Gonzalez et al., 2012; Zeng and Su, 2013), but the magnitude of vapor flow calculated by existing mechanisms is underestimated (Parlange et al., 1998; Zeng et al., 2011a; Zeng et al., 2011b). Considering the coupling of dry airflow may be the key to solving this problem (Schrefler and Zhan, 1993; Parlange et al., 1998; Zeng et al., 2011a). Zeng et al. (2011a) conducted a short-term experiment in the Badain Jaran Desert to investigate the impact of soil dry airflow on soil evaporative flux; the results indicated the advective vapor transfer was weakened if the airflow was neglected, leading to an underestimation error of $33-53 \%$, and the authors suggested more analysis should be conducted with a wider range of soil wetness, soil materials and weather conditions (Zeng et al., 2011b). However, the impact of soil dry airflow on modeling are not fully understood (i.e., its impact on soil heat or water movement), even though there are an increasing number of studies showing the possible need to account for the effects of airflow on soil water and heat transport (Touma and Vauclin, 1986; Schrefler and Zhan, 1993; Prunty and Bell, 2007; Wicky and Hauck, 2017; Yamasaki et al., 2017; Yu et al., 2018; Gao et al., 2020).

In most soil heat and mass balance modeling studies, airflow is implicitly treated as an inert gas. Nevertheless, this assumption is not always valid as soil air can cause convective heat transfer (Wicky and Hauck, 2017), and influence soil water flow in some cases; for instance, inducing liquid/vapor water flow accumulating to the freezing front in frozen soil (Yu et al., 2018). Besides, heavy rainfall or irrigation often entraps air in the soil, which retards infiltration (Linden and Dixon, 1975) and therefore affects the wetting front (Wang et al., 1998; Zeng et al., 2011a; Yang et al., 2021). Thus, it is necessary to compare soil heat and mass transport modeling results considering the soil air flux transport mechanism.

The Simultaneous Transfer of Energy, Mass and Momentum in Unsaturated Soil (STEMMUS) model simulates one-dimensional unsaturated soil hydrothermal transport and crop evapotranspiration dynamics using MATLAB code (Zeng et al., 2011a; Zeng et al., 2011b; Zeng and Su, 2013; Yu et al., 2016); however, it is still in development so its application remains limited. The advantage of STEMMUS is that it considers soil airflow transport mechanism and regards soil airflow as a single phase in soil water and heat transport. The STEMMUS model has not been tested in dry alpine agricultural lands.

According to the census, the northeastern TP has the largest Lycium barbarum L. (also known as Tibetan or Himalayan goji, or Chinese wolfberry) planting area in China $\left(45,000 \mathrm{hm}^{2}\right.$ in 2018). The Lycium barbarum L. industry is one of the most important ecological and inhabitants' livelihood projects, but its growth is limited by water shortage. To provide support for the local agricultural administration, we conducted a numerical simulation in a dry irrigated farmland of the Qaidam Basin, in soils with high gravel and sand contents (Wang et al., 2020) and a thick vadose zone, which we expected to be suitable for adopting an airflow-coupled soil hydrothermal process simulation. The study aimed to: (i) evaluate the performance of the airflow-coupled model for simulating soil moisture, temperature, surface evaporation, and evapotranspiration in dry alpine agricultural land, and (ii) quantify the impacts of incorporating the airflow transport mechanism on soil moisture, temperature, surface evaporation, and evapotranspiration transport.

\section{Materials and methods}

\subsection{Site description}

This study was conducted in the Huaitou Tala Irrigation Region ( $96^{\circ} 44^{\prime}$ E, $37^{\circ} 21^{\prime} \mathrm{N} ; 2869 \mathrm{~m}$ a. s. 1.), a reclaimed area of the Gobi Desert in the northeast of the Qaidam Basin on the TP (Fig. 1). The duration of sunshine is approximately $10 \mathrm{~h}$ per day. The average annual precipitation is about $200 \mathrm{~mm}$, concentrated from June to September, and the average annual soil surface temperature $(1981-2016)$ is $4.5^{\circ} \mathrm{C}$. The irrigation water comes from nearby reservoirs and wells, and the underground water table exceeded $90 \mathrm{~m}$ when surveyed in 2019. The soil at the location is sandy gravel from $0-100 \mathrm{~cm}$, comprising about $82 \%$ sand (particle diameter $0.02-2 \mathrm{~mm}$ ), $10 \%$ silt (particle diameter $0.002-0.02 \mathrm{~mm}$ ), and $8 \%$ clay (particle diameter $<0.002 \mathrm{~mm}$ ) (Table 1). Table 1 also shows other physical characteristics of undisturbed soil samples from 0 to $100 \mathrm{~cm}$ at this site.

The common cultivation practice in this site is unmulched flat planting. In response to China's poverty alleviation project, and to prevent wind and sand fixation, more than 2,900 ha of local area are planted to Lycium barbarum L. due to its property of drought and cold resistance. This species has become the main local cash crop. Hence this study chose the Lycium barbarum L. as the objective. At the start of the experiment, the plants were four years old, on average, with a mean height of $1 \mathrm{~m}$.

\subsection{Observations}

This study was conducted from 28 May to 28 September 2018 and 2019 in accordance with Lycium barbarum L. growth period. Before commencing the experiment, undisturbed soil samples were collected to determine soil physical properties. Soil dry bulk density was measured using the ring knife method (Bao, 2000), saturated water content was determined via the oven drying method after saturating the soil samples for $24 \mathrm{~h}$, and saturated hydraulic conductivity was measured via the double-ring infiltration method (Bao, 2000).

According to Zhang et al. (2016), the depth of the root zone of L. barbarum is about $60 \mathrm{~cm}$. Thus, $5 \mathrm{TM}$ soil moisture and temperature sensors (Meter group, USA) were installed to record hourly root- zone soil volumetric water content and temperature at depths of 20,40, 60, 80 , and $100 \mathrm{~cm}$ with three replications. The daily evaporation rate (E) was averaged from nine replications measured via micro-lysimeters (20 $\mathrm{cm}$ long $\times 12 \mathrm{~cm}$ wide, PVC tubes) at 17:00 every day using a portable electronic balance ( $0.1 \mathrm{~g}$ resolution); changes in the weight of the lysimeters were taken as equivalent to the amount of water evaporated from the soil surface. Evapotranspiration (ET) was averaged from two replications via lysimeter weighting systems $(60 \mathrm{~cm}$ long $\times 40 \mathrm{~cm}$ wide, 


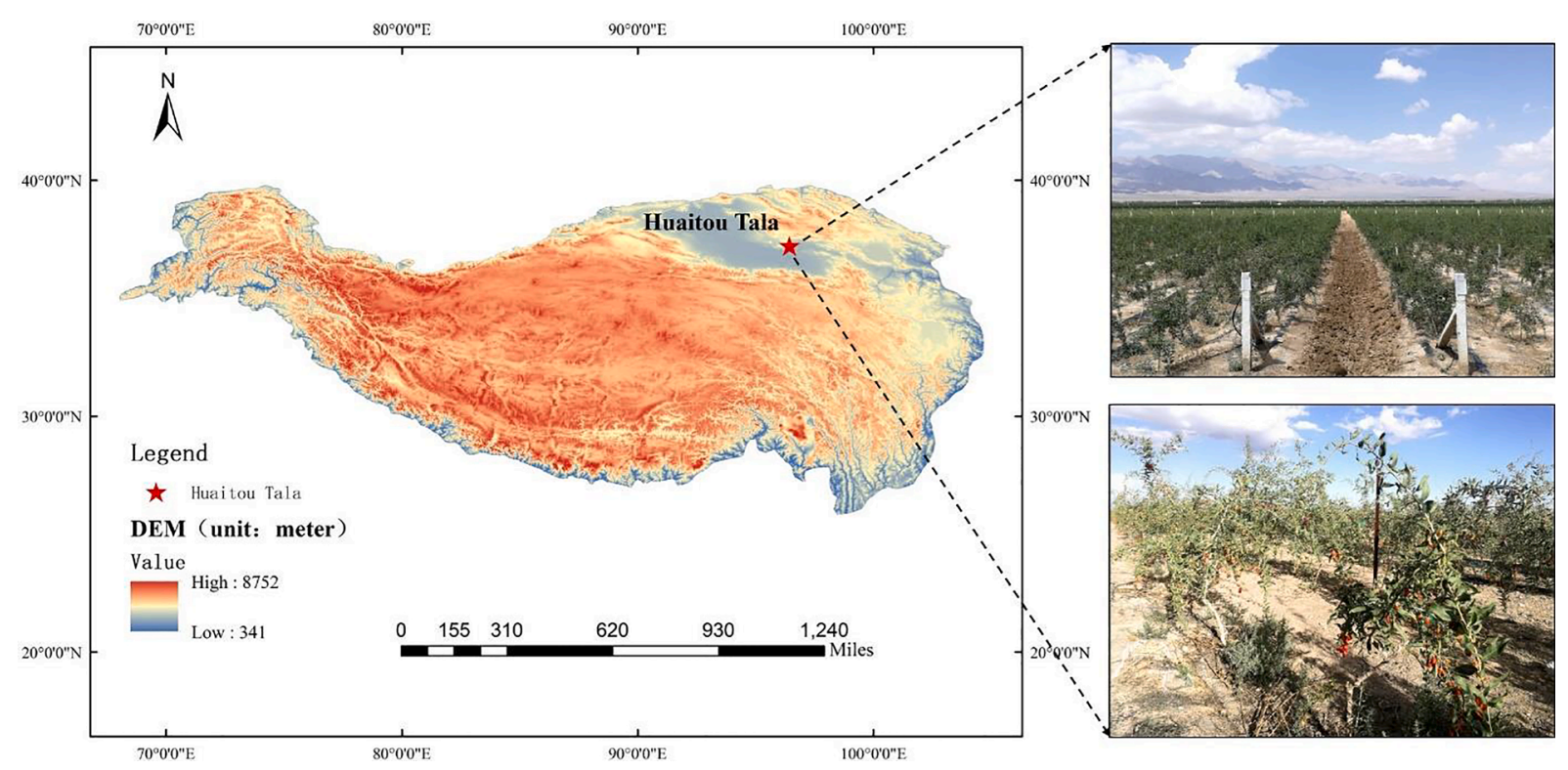

Fig. 1. Geographical location of the experimental site on the Tibetan Plateau.

Table 1

Soil properties in the $0-100 \mathrm{~cm}$ soil layer at the experimental site.

\begin{tabular}{|c|c|c|c|c|c|c|c|c|c|c|c|}
\hline Layer & Sand & Silt & Clay & Bulk density & $\theta_{s}$ & $K_{s}$ & $c_{w}$ & $c_{a}$ & $c_{q}$ & $c_{c}$ & $c_{o}$ \\
\hline $\mathrm{cm}$ & $\%$ & $\%$ & $\%$ & $\mathrm{~g} \mathrm{~cm}^{-3}$ & $\mathrm{~cm}^{3} \mathrm{~cm}^{-3}$ & $\mathrm{~mm} \min ^{-1}$ & $\mathrm{~J} \mathrm{~g}^{-1} \mathrm{~K}^{-1}$ & & & & \\
\hline $0-100$ & 82 & 10 & 8 & 1.52 & 0.41 & 0.83 & 4.18 & 1.01 & 0.80 & 0.90 & 1.92 \\
\hline
\end{tabular}

Note: $c_{w}, c_{a}, c_{q}, c_{c}, c_{o}$ are specific heat capacities for water, air, quartz, clay and organic matter (De Vries, 1963). $\theta_{s}$ and $K_{s}$ are saturated water content and saturated hydraulic conductivity, respectively.

$50 \mathrm{~g}$ resolution), located adjacent to the field. The variety and tree-age of L. barbarum transplanted into lysimeters were the same as the field plants, with a similar growth status. The taproot length at transplantation was approximately $20 \mathrm{~cm}$. During the growing period, ET was automatically monitored hourly and summed to daily values. The lysimeter system contained a weighing facility, filter layer (filled with stone), and outfall at the bottom of each lysimeter. During the two-year experiment, no seepage was recorded. Hourly air temperature, precipitation, relative humidity, and wind speed at $2 \mathrm{~m}$ height were recorded with an automatic weather station (Meter group, USA) placed in the study area.

For each growing season, plant height was measured with a tape measure and leaf area index (LAI) was measured using an LAI-2200C Plant Canopy Analyzer (Meter Group, USA). Stomatal conductance was measured monthly with an LI-6400 instrument (Meter Group, USA) between 9 and 11 am on sunny days. Daily LAI, plant height and stomatal conductance values were linearly interpolated from the observations and used to calculate crop evapotranspiration (Allen et al., 1998).

Surface drip irrigation was applied six times a year-about 13.4 (2018) and $25.8 \mathrm{~mm}$ (2019) on each occasion - with unitive fertilizer nutrients (content of total nitrogen, water-soluble phosphorus, watersoluble potassium $\geq 20 \%$ ). No surface runoff occurred during the experiment.

\subsection{Model configuration}

\subsubsection{Governing equations}

The governing equation for soil water flux in STEMMUS is based on the model by Milly (1982):

$\frac{\partial}{\partial t}\left(\rho_{L} \theta_{L}+\rho_{V} \theta_{v}\right)=-\frac{\partial}{\partial z}\left(q_{L}+q_{V}\right)-S$ where $t$ is time (s), $\rho_{L}$ and $\rho_{V}$ are densities of liquid water and water vapor $\left(\mathrm{kg} \mathrm{m}^{-3}\right)$, respectively; $\theta_{L}$ and $\theta_{V}$ are volumetric water content and water vapor content $\left(\mathrm{m}^{3} \mathrm{~m}^{-3}\right)$, respectively; $z$ is the vertical space coordinate, positive upwards (m); $q_{L}$ and $q_{V}$ are liquid and vapor fluxes, respectively $\left(\mathrm{kg} \mathrm{m}^{-2} \mathrm{~s}^{-1}\right)$; and $S$ is a sink term representing water uptake by plant roots $\left(\mathrm{kg} \mathrm{m}^{-3} \mathrm{~s}^{-1}\right)$. In addition to the existing mechanisms included in Milly's model, the effect of thermal liquid flux and the dry air phase (i.e., dispersive water vapor flux and water vapor flux as part of the bulk flow of dry air) are considered in STEMMUS (Zeng et al., 2011a).

Heat transport in unsaturated soil includes heat transfer of solids, liquids, vapor flux, and dry air flux, as well as integral heat wetting (De Vries, 1958). As such, the conservation of heat transfer is expressed as:

$$
\begin{array}{r}
\frac{\partial}{\partial t}\left[\left(\rho_{s} \theta_{s} c_{s}+\rho_{L} \theta_{L} c_{L}+\rho_{d a} \theta_{a} c_{a}+\rho_{v} \theta_{V} c_{v}\right)\left(T-T_{r}\right)+\rho_{V} L_{0} \theta_{V}\right]-\rho_{L} W \frac{\partial \theta_{L}}{\partial t} \\
=\frac{\partial}{\partial z}\left(\lambda_{e f f} \frac{\partial T}{\partial z}\right)-\frac{\partial}{\partial z}\left\{q_{L} c_{L}\left(T-T_{r}\right)+q_{v}\left[L_{0}+c_{v}\left(T-T_{r}\right)\right]+q_{a} c_{a}\left(T-T_{r}\right)\right\}
\end{array}
$$

(2) where $\rho_{d a}$ and $\rho_{s}$ are densities of soil dry air and solid $\left(\mathrm{kg} \mathrm{m}^{-3}\right)$, respectively; $\theta_{s}$ and $\theta_{a}$ are volumetric contents of solid and gas in soil (m $\mathrm{m}^{3}$ $\left.\mathrm{m}^{-3}\right)$, respectively; $c_{s}, c_{L}, c_{a}$, and $c_{v}$ are specific heat capacities $\left(\mathrm{J} \mathrm{g}^{-1}\right.$ $\mathrm{K}^{-1}$ ) of solids, liquids, air, and vapor, respectively; $T$ is soil temperature $\left({ }^{\circ} \mathrm{C}\right) ; T_{r}$ is a reference temperature $\left({ }^{\circ} \mathrm{C}\right) ; L_{0}$ is volumetric latent heat of vaporization of liquid water $\left(\mathrm{J} \mathrm{kg}^{-1}\right)$; $W$ is differential heat of wetting $(\mathrm{J}$ $\left.\mathrm{kg}^{-1}\right) ; \lambda_{e f f}$ is effective thermal conductivity $\left(\mathrm{W} \mathrm{m}^{-1}{ }^{\circ} \mathrm{C}^{-1}\right)$; and $q_{a}$ is soil dry air flux $\left(\mathrm{kg} \mathrm{m}^{-2} \mathrm{~s}^{-1}\right)$.

According to the theory of dry airflow proposed by Thomas and Sansom (1995), dry air flux includes both the bulk flow of dry air and air dissolved in liquid, expressed as: 
$\frac{\partial}{\partial t}\left[\eta \rho_{d a}\left(S_{a}+H_{c} S_{L}\right)\right]=\frac{\partial}{\partial z}\left[D_{V} \frac{\partial \rho_{d a}}{\partial z}+\rho_{d a} \frac{S_{a} k_{g}}{\mu_{a}} \frac{\partial P_{g}}{\partial z}+\left(\theta_{a} D_{V g}\right) \frac{\partial \rho_{d a}}{\partial z}-H_{c} \rho_{d a} \frac{q_{L}}{\rho_{L}}\right]$

where $\eta$ is porosity, $S_{L}$ is degree of saturation of the soil, $S_{a}$ is degree of air saturation of the soil, $H_{c}$ is Henry's constant (set to 0.02), $D_{V}$ is molecular diffusivity of water vapor in soil $\left(\mathrm{m}^{2} \mathrm{~s}^{-1}\right), k_{g}$ is intrinsic air permeability $\left(\mathrm{m}^{2}\right), \mu_{a}$ is air viscosity (set to $1.846 \times 10^{5} \mathrm{~kg} \mathrm{~m}^{-1} \mathrm{~s}^{-1}$ ), $P_{g}$ is pore-air pressure $(\mathrm{Pa})$, and $D_{V g}$ is gas-phase longitudinal dispersion coefficient $\left(\mathrm{m}^{2} \mathrm{~s}^{-1}\right)$. On the right hand side of Eq. (3), the first and third items are expressions of the diffusive and dispersive components of dry air flux based on Fick's law, respectively; the second item represents the advective flux of dry air calculated by Darcy's law; and the fourth represents the amount of air that will dissolve in liquid at mechanical and chemical equilibrium (Henry's law).

The evapotranspiration rate is estimated using the revised PenmanMonteith (P-M) model (Yu et al., 2016):

$T_{p}=\frac{\Delta\left(R_{n}^{c}-G\right)+\rho_{a} c_{p} \frac{\left(e_{s}-e_{a}\right)}{r_{a}^{c}}}{\lambda\left(\Delta+\gamma\left(1+\frac{r_{c m i n}}{r_{a}^{c}}\right)\right)}$

$E_{s}=\frac{\Delta\left(R_{n}^{s}-G\right)+\rho_{a} c_{p} \frac{\left(e_{s}-e_{a}\right)}{r_{a}^{s}}}{\lambda\left(\Delta+\gamma\left(1+\frac{r_{s}}{r_{a}^{s}}\right)\right)}$

where $G$ is soil heat flux density $\left(\mathrm{MJ} \mathrm{m}^{-2} \mathrm{~d}^{-1}\right) ; \lambda$ is latent heat of vaporization $\left(\mathrm{MJ} \mathrm{kg}^{-1}\right) ; \Delta$ is the slope of the vapor pressure curve (k Pa $\left.{ }^{\circ} \mathrm{C}^{-1}\right) ; \gamma$ is the psychrometric constant $\left(\mathrm{k} \mathrm{Pa}{ }^{\circ} \mathrm{C}^{-1}\right) ; e_{a}$ and $e_{s}$ are actual and saturation vapor pressures $(\mathrm{kPa})$, respectively; $R_{n}^{c}$ and $R_{n}^{s}$ are net radiation at the canopy surface and soil surface $\left(\mathrm{MJ} \mathrm{m}^{-2} \mathrm{~d}^{-1}\right)$, respectively; $c_{p}$ is specific heat $\left(\mathrm{J} \mathrm{kg}^{-1}{ }^{\circ} \mathrm{C}^{-1}\right)$ of air; $\rho_{a}$ is air density $\left(\mathrm{kg} \mathrm{m}^{-3}\right), r_{a}^{c}$ and $r_{a}^{s}$ are aerodynamic resistances of the canopy surface and bare soil $\left(\mathrm{s} \mathrm{m}^{-1}\right)$, respectively; $r_{c m i n}$ is minimum canopy surface resistance $\left(\mathrm{s} \mathrm{m}^{-1}\right)$; and $r_{s}$ is soil surface resistance $\left(\mathrm{s} \mathrm{m}^{-1}\right)$.

\subsubsection{Constitutive equations}

The isothermal hydraulic conductivity $K_{L h}\left(\mathrm{~m} \mathrm{~s}^{-1}\right)$ is calculated using the van Genuchten-Mualem model (van Genuchten, 1980):

$K_{L h}(h)=K_{S} S_{e}^{l}\left[1-\left(1-S_{e}^{1 / m}\right)^{m}\right]^{2}$

$S_{e}=\frac{\theta-\theta_{r}}{\theta_{s}-\theta_{r}}$

where $h$ is the pressure head $(\mathrm{cm}), K_{S}$ is the saturated hydraulic conductivity ( $\mathrm{m} \mathrm{s}^{-1}$ ); $\theta_{r}$ and $\theta_{s}$ are the residual and saturated volumetric water contents $\left(\mathrm{m}^{3} \mathrm{~m}^{-3}\right)$, respectively; $\mathrm{m}$ is the empirical shape parameter (dimensionless); $l$ is set to 0.5 (dimensionless); and $S_{e}$ is the relative saturation (dimensionless) .

Specific heat capacities $\left(\mathrm{J} \mathrm{g}^{-1} \mathrm{~K}^{-1}\right.$ ) of relevant solids, liquid, air and vapor were obtained from De Vries (1963) (Table 1). Effective thermal conductivity and root water uptake were calculated using the models presented by Chung and Horton (1987) and Feddes et al. (1978), respectively (Table S1). The variable definitions in STEMMUS are shown in Table S2.

\subsubsection{Model domain}

Based on the conservation equations for moisture, energy, and dry air, three coupled partial differential equations were solved simultaneously using Galerkin's finite element method for spatial discretization and a fully implicit backward difference approach for temporal discretization. The model domain was a $3.0 \mathrm{~m}$ deep profile, with instrumented observation nodes at 20,40,60, 80, and $100 \mathrm{~cm}$ depths. There were 38 discretization nodes in the model domain and the spatial discretization size was $1 \mathrm{~cm}$ for the top $0.1 \mathrm{~m}$ layer, $1.5 \mathrm{~cm}$ for the $0.1-0.2$ $\mathrm{m}$ layer, $5 \mathrm{~cm}$ for the $0.2-0.6 \mathrm{~m}$ layer, and $10 \mathrm{~cm}$ for the $0.6-1.0 \mathrm{~m}$ layer. The temporal step was set at $1 \mathrm{~h}$.

\subsubsection{Initial and boundary conditions}

Soil moisture and temperature measured at the beginning of each simulation were taken as the initial conditions, and the initial soil air pressure was set as atmospheric pressure, expressed as:

$\left.\theta(z, t)\right|_{t=0}=\theta_{0}(z)$

$\left.T(z, t)\right|_{t=0}=T_{0}(z)$

$\left.P_{g}(z, t)\right|_{t=0}=P_{g 0}(z)$

where $t$ is time (s), $z$ is the vertical space coordinate, $\left.\theta(z, t)\right|_{t=0}$ and $T(z$, $t)\left.\right|_{t=0}$ are the initially measured soil volumetric water content $\left(\mathrm{cm}^{3}\right.$ $\mathrm{cm}^{-3}$ ) and temperature $\left({ }^{\circ} \mathrm{C}\right)$, respectively, $\left.P_{g}(z, t)\right|_{t=0}$ is the initial soil air pressure set as atmospheric pressure.

The upper boundary for water transport was set by atmospheric forcing, compounded with soil evaporation, precipitation and irrigation, expressed as:

$\left.\left(q_{L}+q_{V}\right)\right|_{z=0}=E-\rho_{L}(P+I)$

where $E, P$ and $I$ are actual evaporation flux $\left(\mathrm{kg} \mathrm{m}^{-2} \mathrm{~s}^{-1}\right)$, and precipitation and irrigation rates $\left(\mathrm{m} \mathrm{s}^{-1}\right)$, respectively.

The bottom boundary for water transport was taken as free drainage. The measured upper and bottom soil temperatures were set as corresponding boundary conditions for heat transport. For dry air transport, the measured atmospheric pressure was adopted as the surface upper condition, and the zero soil-air pressure gradient was set as the bottom condition.

To achieve a reasonable tradeoff between computational effort and accuracy of the solution, the prescribed upper limits of independent variables were used to determine a new time step size automatically (Milly, 1982) in the form of:

$\Delta t=\min \left[\frac{X_{\max }}{\max _{i}\left(\frac{d \theta_{i}}{d t}\right)}, \frac{T_{\max }}{\max _{i}\left(\frac{d T_{i}}{d t}\right)}, \frac{P_{g_{\max }}}{\max _{i}\left(\frac{d P_{g_{i}}}{d t}\right)}, \frac{h_{\max }}{\max _{i}\left(\frac{d h_{i}}{d t}\right)}\right]$

where $\max _{i}$ denotes maximization over all nodes $i$ is the changes in state variables estimated from the most recent time step, and $X_{\max }, T_{\max }, P_{g_{\max }}$ and $h_{\max }$ are the upper limits of change for volumetric water content, temperature, atmospheric pressure, and matric potential, respectively. If the change exceeds the desired upper limits, the calculation of that time step is erroneous, and the time step will be repeated with a reduced time length.

\subsection{Model parameterization}

\subsubsection{Soil hydraulic parameters}

The root zone soil profiles were uniformly divided into five layers to a depth of $1 \mathrm{~m}$. Soil bulk density, saturated water content, and saturated hydraulic conductivity were measured for each of the five layers in the laboratory. The averaged soil bulk density was $1.52 \mathrm{~g} \mathrm{~cm}^{-3}$ and the saturated hydraulic conductivity was $0.83 \mathrm{~mm} \mathrm{~min}^{-1}$ (Table 1 ). The saturated water content was originally measured using the gravimetric method and then transformed to volumetric water content of $0.41 \mathrm{~cm}^{3}$ $\mathrm{cm}^{-3}$ by multiplying bulk density. Initial coefficients of the V-G model were obtained via the pedotransfer function (PTF) presented by Ugbaje and Reuter (2013), and equal to $1.654(\mathrm{n}), 0.034(\alpha)$, and $0.05\left(\theta_{\mathrm{r}}\right)$, respectively. The clay fraction of soils was determined using a Mastersizer 2000 Laser Particle Size Analyzer (Malvern, UK); the 0-100 cm average value was 0.08 . 


\subsubsection{Crop parameters}

The initial light attenuation coefficient, parameters dependent on soil texture, were cited from Yu et al. (2016), setting to 0.39, 0.68 and 2.0 , respectively. Since we did not found the related $L$. barbarum evapotranspiration parameters before, we determined the crop coefficient at effective full ground cover according to Allen et al. (1998), and set it to 1.1 (for $1 \mathrm{~m}$ height fruit tree).

The initial extinction coefficient was assumed at 0.6 according to $\mathrm{Yu}$ et al. (2016). While a previous study specifically discussed and derived the dynamic extinction coefficient from measured plant transpiration as a function of LAI (Tahiri et al., 2006), it is convenient to consider it as constant (Allen et al., 1998; Yu et al., 2016). A piecewise linear function, defined in Feddes et al. (1978), was used to describe the response of roots to the soil water pressure head. The input water stress parameters were $-10 \mathrm{~cm}\left(\mathrm{H}_{1}\right)$ for the water potential below which roots start to extract water; $-30 \mathrm{~cm}\left(\mathrm{H}_{2}\right)$ for the water potential below which roots extract water at the maximum possible rate; higher limit $-650 \mathrm{~cm}\left(\mathrm{H}_{3 \mathrm{H}}\right)$ and lower limit $-800 \mathrm{~cm}\left(\mathrm{H}_{3 \mathrm{~L}}\right)$ for the limiting water potential values below which roots can no longer extract water at the maximum rate; $-5000 \mathrm{~cm}\left(\mathrm{H}_{4}\right)$ for the water potential below which root water uptake ceases. Minimum soil moisture for potential evaporation is used to calculate soil surface resistance (Van De Griend and Owe, 1994) and assumed to be $0.25 \mathrm{~cm}^{3} \mathrm{~cm}^{-3}$ initially.

\subsection{Sensitivity test}

To identify influential parameters in the airflow - coupled soil moisture simulation, a series of sensitivity tests were executed before modeling by using one - factor - at - a - time (OAT) methodology (Arunrat et al., 2018), expressed as:

$A_{s w c i}=\frac{\left|S W C_{1.1 X_{i}}-S W C_{X_{i}}\right|+\left|S W C_{0.9 X_{i}}-S W C_{X_{i}}\right|}{0.2 S W C_{X_{i}}}$

where $A_{s w c i}$ is the sensitivity coefficient of parameter $X_{i}$ for soil water content; $S W C_{X_{i}}$ is the simulated soil water content obtained by setting all parameters to default values; and $S W C_{1.1 X_{i}}$ and $S W C_{0.9 X_{i}}$ are simulated soil water contents obtained by setting parameter $X_{i}$ to $110 \%$ and $90 \%$ of its default value, respectively, and all other parameters to default values. The sensitivity coefficient ranges from 0 (non-sensitivity) to 1 (extremesensitivity), with higher values representing higher sensitivity.

\subsection{Validation test}

Data collected in the first year (2018) was used to calibrate the model (Figs. S2, S3, S4), and data collected in the second year was used to assess model performance. The quality of model predictions was certified by calculating the root mean squared error (RMSE) and the index of agreement $(d)$ was adopted as additional supporting information for a better understanding of RMSE.

$R M S E=\sqrt{\frac{1}{n} \sum_{i=1}^{n}\left(M_{i}-P_{i}\right)^{2}}$

$d=1-\frac{\sum_{i=1}^{n}\left(P_{i}-M_{i}\right)^{2}}{\sum_{i=1}^{n}\left(\left|P_{i}-M\right|+\left|M_{i}-M\right|\right)^{2}}$

where $P_{i}$ is a predicted value, $M_{i}$ is the corresponding measured value, $\bar{M}$ is the mean measured values, $i$ is the number of measurements, and $n$ is the test dataset size. The $d$ value ranges from 0 to 1 . If the evaluated model accurately depicts the datasets, $d$ should be close to 1 , while low RMSE values indicate that most predictions are close to the observations.

\section{Results}

\subsection{Meteorological variables}

The monitored $2 \mathrm{~m}$ height meteorological variables at the experimental site are presented in Fig. 2. The experimental site is in a high altitude area, with a typical continental plateau climate, featuring low air oxygen concentration, low temperature, dry winds, and strong solar radiation. The average air temperature over the two years was $16^{\circ} \mathrm{C}$, and average air pressure was $72 \mathrm{kPa}$. The highest daily solar radiation reached $8000 \mathrm{Wh} \mathrm{m}^{-2}$ day $^{-1}$, while the recorded precipitation during crop growth period only attained $141 \mathrm{~mm}$ and $135 \mathrm{~mm}$, respectively, in 2018 and 2019, mainly concentrated in the vegetative growth stage. Potential evapotranspiration at the experimental site is very high, especially during vegetative growth, often reaching $6 \mathrm{~mm} \mathrm{~d}^{-1}$. During crop growth, the vapor pressure deficit (VPD) waved unstably, as the calculated saturation vapor pressure was averaged to $2 \mathrm{kPa}$ while actual local vapor pressure was approximately $0.9 \mathrm{kPa}$, resulting in strong potential evaporation.

\subsection{Sensitivity analysis}

We expected that parameters with $\mathrm{A}_{\mathrm{swci}}$ values larger than 0.3 would impact simulations. The sensitivity tests showed that varying the parameters in the water flow module generated relatively large differences in modeling results, with four of the nine parameters with $\mathrm{A}_{\text {swci }}$ values greater than 0.3 , while $\mathrm{K}_{\mathrm{s}}$ attained this baseline. In contrast, only two of the 11 crop evapotranspiration module parameters had $\mathrm{A}_{\text {swci }}$ values slightly above 0.3 (Table 2). Most of the influential parameters were soil hydraulic parameters. The strongest influential parameter for soil moisture modeling was a $\mathrm{V}-\mathrm{G}$ equation coefficient (n), with an $\mathrm{A}_{\text {swci }}$ value of 0.9. $A_{\text {swci }}$ values for the identified influential parameters were ranked as follows: $\mathrm{n}>\theta_{\mathrm{s}}>\alpha>\eta>\theta_{\min }>\mathrm{H}_{4}>\mathrm{K}_{\mathrm{s}}$.

\subsection{Modeling performance}

\subsubsection{Soil temperature and moisture}

Fig. S2 shows the calibration results of airflow - coupled soil temperature at soil depths of $20,40,60,80$, and $100 \mathrm{~cm}$. Due to unexpected destruction, several days' soil temperature and moisture data were lost (Figs. S2 and S3), but soil temperature of different layers was simulated well in the whole crop growing period, The calculated index of agreement $(d)$ and RMSE ranged from 0.96 to 0.98 and $1.55{ }^{\circ} \mathrm{C}$ to $2.1{ }^{\circ} \mathrm{C}$ at 20-100 cm soil profile, respectively. For the validation results (Fig. 3), during the growing season, observed soil temperature variations mainly occurred in shallow soil layers. STEMMUS satisfactorily captured the observations at the monitored depths. The calculated index of agreement $(d)$ and $R M S E$ ranged from 0.93 to 0.95 and $0.77{ }^{\circ} \mathrm{C}$ to $1.04{ }^{\circ} \mathrm{C}$ at $20-100 \mathrm{~cm}$ soil profile, respectively, with an averaged value of 0.94 .

The soil moisture simulations were acceptable for both calibration and validation stages (Figs. S3 and 4), with average values for $d$ in the $20-100 \mathrm{~cm}$ soil profile of 0.85 and 0.83 , respectively. The moisture dynamics at $20-40 \mathrm{~cm}$ soil depths corresponding to rainfall/irrigation events were well - modeled, with values for $d$ and RMSE for validation stage reaching 0.93 and $0.01 \mathrm{~cm}^{3} \mathrm{~cm}^{-3}$ respectively. However, simulations at $60 \mathrm{~cm}$ depth were not as good as in the shallow layers; apparent underestimation was observed under the calibration stage, while at the validation stage, the observations wavered slightly through the whole growing period due to limited water input whereas the simulated values exhibited the more intense responses to rainfall/irrigation and underestimated the observations. At $100 \mathrm{~cm}$, the observations were portrayed well by the simulations, with $d$ andRMSE values reaching 0.96 and 0.01 $\mathrm{cm}^{3} \mathrm{~cm}^{-3}$ respectively (Fig. 4).

\subsubsection{Evapotranspiration and soil evaporation}

The growth of Lycium barbarum L. begins in late May and ends at the 

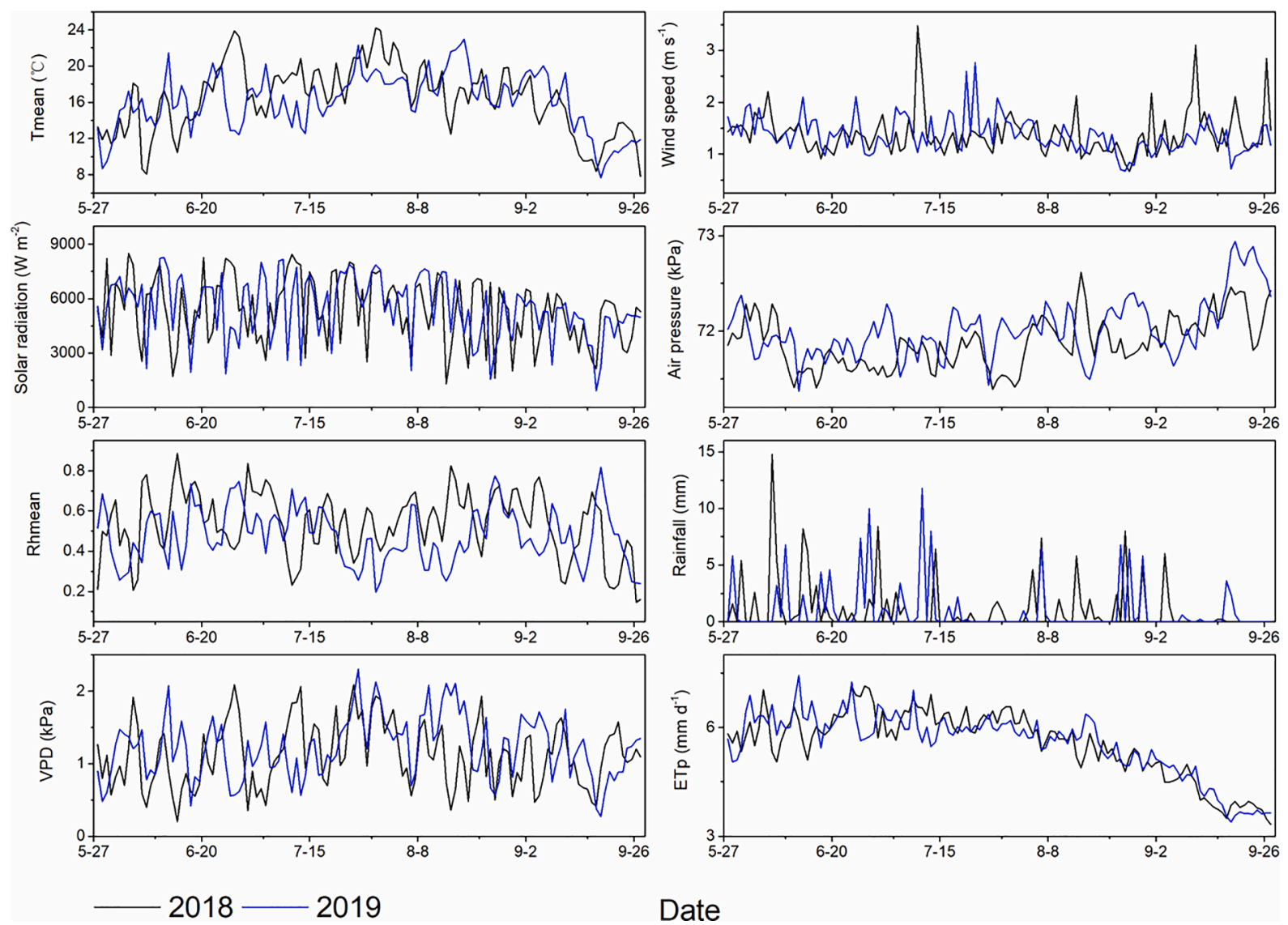

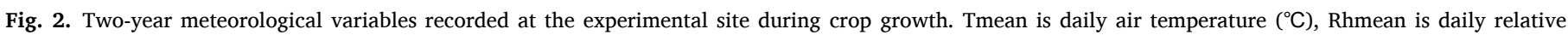
humidity (\%), VPD is daily vapor pressure deficit (kPa) and ETp is daily potential evapotranspiration $\left(\mathrm{mm}^{-1}\right)$.

end of September, then enters dormancy. The simulations for daily crop evapotranspiration agreed acceptably with the observations during the whole growing period (Figs. S4 and 5). The $d$ values attained 0.68 and 0.83 , and RMSE values attained $0.99 \mathrm{~mm} \mathrm{~d}^{-1}$ and $1.07 \mathrm{~mm} \mathrm{~d}^{-1}$ respectively, for the calibration and validation stages.

The simulations for daily soil evaporation were similar to the results of evapotranspiration. The variations in precipitation/irrigation were well portrayed, with only a few significant modeling errors were found across the entire growing season, with values for $d$ and RMSE reaching 0.72 and $0.53 \mathrm{~mm} \mathrm{~d}^{-1}$ respectively (Fig. 5).

\subsection{Impact of soil dry airflow}

Simulation differences when including the soil airflow mechanism occurred after rainfall or irrigation events, but not significantly (Fig. 6). Considering soil airflow transport immediately elevated the downward water vapor flux and liquid water flux after rainfall or surface irrigation, increasing the soil moisture modeling values and closing the observation gap. We therefore divided the simulated results throughout the whole growing season into periods of non-rainfall/irrigation (inter - rainfall) and rainfall/irrigation (intra - rainfall), and results indicated that irrespective of an inter - or intra - rainfall (or irrigation) period, considering soil airflow transport had little effects on the simulation of soil temperature (Fig. 7). We used RMSE here as it showed clear differences for comparisons. The most apparent difference occurred at $60 \mathrm{~cm}$, where considering soil dry airflow reduced RMSE by $1.1 \%$ during the intrarainfall period.

Incorporating airflow successfully improved soil moisture and evapotranspiration modeling precision when the water input from rainfall/irrigation reached $22.8 \mathrm{~mm}$ and beyond (Figs. 8 and 9). In comparison with the soil moisture simulations neglecting soil dry airflow, considering airflow reduced RMSE from $0.0 \%$ to $92.5 \%$ at $20 \mathrm{~cm}$ soil depth; beyond that depth, the improvements were less evident, with maximum reductions of $95.9 \%, 34.5 \%, 15.5 \%$, and $6.7 \%$ at $40,60,80$, and $100 \mathrm{~cm}$, respectively. The airflow - coupled simulation reduced the evapotranspiration RMSE from $0.0 \%$ to $97.8 \%$ and evaporation RMSE from $0.0 \%$ to $99.3 \%$.

We thereafter integrated all the 35 rainfall/irrigation events during the validation period to compare the magnitude of water input on the airflow-coupled simulation (Fig. 10). For soil temperature, modeling values considering airflow presented the same but negligible increment as rainfall/irrigation amount; of which the increase was limited to $0.1{ }^{\circ} \mathrm{C}$ at most soil depths. The soil moisture modeling values when considering airflow at shallow soil layers also showed positive relationships with increasing water inputs-a $10 \mathrm{~mm}$ increase in rainfall/irrigation increased moisture modeling values by $0.2 \%$ at $20 \mathrm{~cm}$ soil depth, and the maximum increment reached $0.6 \%$, while the obvious positive relationship between airflow and water inputs gradually weakened with depth. No clear distinctions were evident between the simulations with and without airflow at $100 \mathrm{~cm}$ soil depth. Airflow-coupled evapotranspiration and evaporation modeling values also had positive correlations with water inputs, with maximum values all approaching $0.2 \mathrm{~mm} \mathrm{~d}^{-1}$, when water inputs increased to $30 \mathrm{~mm}$.

\section{Discussion}

Sensitivity analysis can be used to quickly identify sensitive parameters in modeling results and reduce the time required for calibrating parameters. Our sensitivity tests indicated that relatively influential parameters for airflow-coupled soil moisture prediction included soil hydraulic properties $\left(\mathrm{K}_{\mathrm{s}}, \theta_{\mathrm{s}}, \mathrm{n}, \alpha\right.$, and $\left.\eta\right)$ and coefficients of the evapotranspiration equation $\left(\mathrm{H}_{4}\right.$ and $\left.\theta_{\min }\right)$ (Table 2). These results are 
Table 2

Sensitivity analysis for STEMMUS.

\begin{tabular}{|c|c|c|c|c|c|}
\hline No. & Parameter & Symbol & $\begin{array}{l}\text { Default } \\
\text { value }\end{array}$ & $\begin{array}{l}\text { Calibrated } \\
\text { value }\end{array}$ & $\mathrm{A}_{\text {swci }}$ \\
\hline \multicolumn{6}{|c|}{ Crop evapotranspiration module } \\
\hline 1 & $\begin{array}{l}\text { Light attenuation } \\
\text { coefficient }(/)\end{array}$ & $\zeta$ & 0.39 & 0.5 & 0.24 \\
\hline 2 & \multirow{3}{*}{$\begin{array}{l}\text { Parameters dependent on } \\
\text { soil texture }(/) \\
\text { Crop coefficient at } \\
\text { effective full ground cover } \\
(/)\end{array}$} & $\mathrm{k}$ & 0.68 & 0.8 & 0.11 \\
\hline 3 & & $\mathrm{~m}$ & 2.0 & 2.3 & 0.23 \\
\hline 4 & & $\mathrm{~K}_{\mathrm{cbmax}}$ & 1.10 & 1.25 & 0.11 \\
\hline 5 & Extinction coefficient $(/)$ & $\tau$ & 0.6 & 0.8 & 0.11 \\
\hline 6 & \multirow{5}{*}{$\begin{array}{l}\text { Water stress function } \\
\text { parameters }(\mathrm{cm})\end{array}$} & $\mathrm{H}_{1}$ & -10 & -15 & 0.10 \\
\hline 7 & & $\mathrm{H}_{2}$ & -30 & -35 & 0.12 \\
\hline 8 & & $\mathrm{H}_{4}$ & -5000 & -6000 & 0.33 \\
\hline 9 & & $\mathrm{H}_{3 \mathrm{~L}}$ & -800 & -600 & 0.24 \\
\hline 10 & & $\mathrm{H}_{3 \mathrm{H}}$ & -650 & -500 & 0.13 \\
\hline 11 & $\begin{array}{l}\text { Minimum soil moisture for } \\
\text { potential evaporation }\left(\mathrm{cm}^{3}\right. \\
\left.\mathrm{cm}^{-3}\right)\end{array}$ & $\theta_{\min }$ & 0.3 & 0.25 & 0.35 \\
\hline \multicolumn{6}{|c|}{ Water flow module } \\
\hline 1 & $\begin{array}{l}\text { Saturation hydraulic } \\
\text { conductivity }\left(\mathrm{mm} \mathrm{min}^{-1}\right)\end{array}$ & $\mathrm{K}_{\mathrm{s}}$ & 0.83 & 0.81 & 0.30 \\
\hline 2 & $\begin{array}{l}\text { Saturated water content } \\
\left(\mathrm{cm}^{3} \mathrm{~cm}^{-3}\right)\end{array}$ & $\theta_{\mathrm{s}}$ & 0.41 & 0.38 & 0.45 \\
\hline 3 & $\begin{array}{l}\text { Residual water content } \\
\left(\mathrm{cm}^{3} \mathrm{~cm}^{-3}\right)\end{array}$ & $\theta_{\mathrm{r}}$ & 0.05 & 0.04 & 0.18 \\
\hline 4 & $\begin{array}{l}\text { Coefficient in V-G model } \\
(/)\end{array}$ & $\mathrm{n}$ & 1.654 & 1.702 & 0.90 \\
\hline 5 & $\begin{array}{l}\text { Coefficient in V-G model } \\
\text { (/) }\end{array}$ & $\alpha$ & 0.034 & 0.004 & 0.44 \\
\hline 6 & Soil porosity $(/)$ & $\eta$ & 0.43 & 0.45 & 0.39 \\
\hline 7 & The fraction of clay $(/)$ & $\mathrm{f}$ & 0.036 & 0.025 & 0.21 \\
\hline
\end{tabular}

Note: $\theta_{\mathrm{s}}, \mathrm{K}_{\mathrm{s}}$ and $\eta$ were measured in the laboratory. Other default parameters in the V-G model were obtained via the pedotransfer function (PTF) presented by Ugbaje and Reuter (2013) and the initial parameters of the Feddes equation were obtained from the HYDRUS database (Šimůnek and van Genuchten, 2008). consistent with those of Ren et al. (2016), who also adopted the V-G and Feddes models to portray soil water dynamics. The most influential parameter was a coefficient of the V-G equation, confirming the importance of soil hydraulic functions in soil moisture modeling (Vereecken et al., 2010; Luo et al., 2019).

To our best knowledge, most simulation studies related to soil hydrothermal processes on the TP have focused on large-scale soil surface moisture retrieval (Bi et al., 2016; Wang et al., 2016; Yang et al., 2016; Zheng et al., 2018), streamflow simulation (Bai et al., 2016), or responses to climate change (Yang et al., 2011; Xue et al., 2014; Fan et al., 2019; Zhang et al., 2019), or the soil freeze - thaw process (Hu et al., 2015; Yu et al., 2018, 2020; Yang and Wang, 2019; Luo et al., 2020). There are no studies on root-zone soil hydrothermal dynamics simulation during crop growth period in dry alpine agricultural regions. The harsh climatic environment of the alpine agricultural region and local coarse-textured soils have posed a challenge for data acquisition. Based on the calibrated parameters in the current study, STEMMUS portrayed soil temperature dynamics well within the vadose zone of alpine agricultural fields under local traditional cultivation practice. The simulated soil temperatures were consistent with the observations (Fig. 3). Including airflow did not exert obvious effects on simulation accuracy but still increased modeling values slightly right after rainfall/irrigation events, which was aligned with a previous report (Zeng et al., 2011a). In addition to parameters (such as airflow equation's or heat equation's) or other possible uncertainties (such as the modeling result not converging) which could influence airflow coupled soil heat transfer as a previous study indicated (Martínez et al., 2016). A possible explanation for slight increment was the inclusion of effects of the air pressure gradient retarded water vapor transport which caused more water vapor to be condensed and consequently the release of latent heat, thus causing a temporary rise in the medium temperature (Zeng et al., 2011a). The high air velocity and open column actually provide a path for the air to escape, creating a condition for the air in the soil column to equilibrate quickly with the atmospheric pressure, which minifies the air pressure head gradients and leads to a small advective effect on soil vapor flow

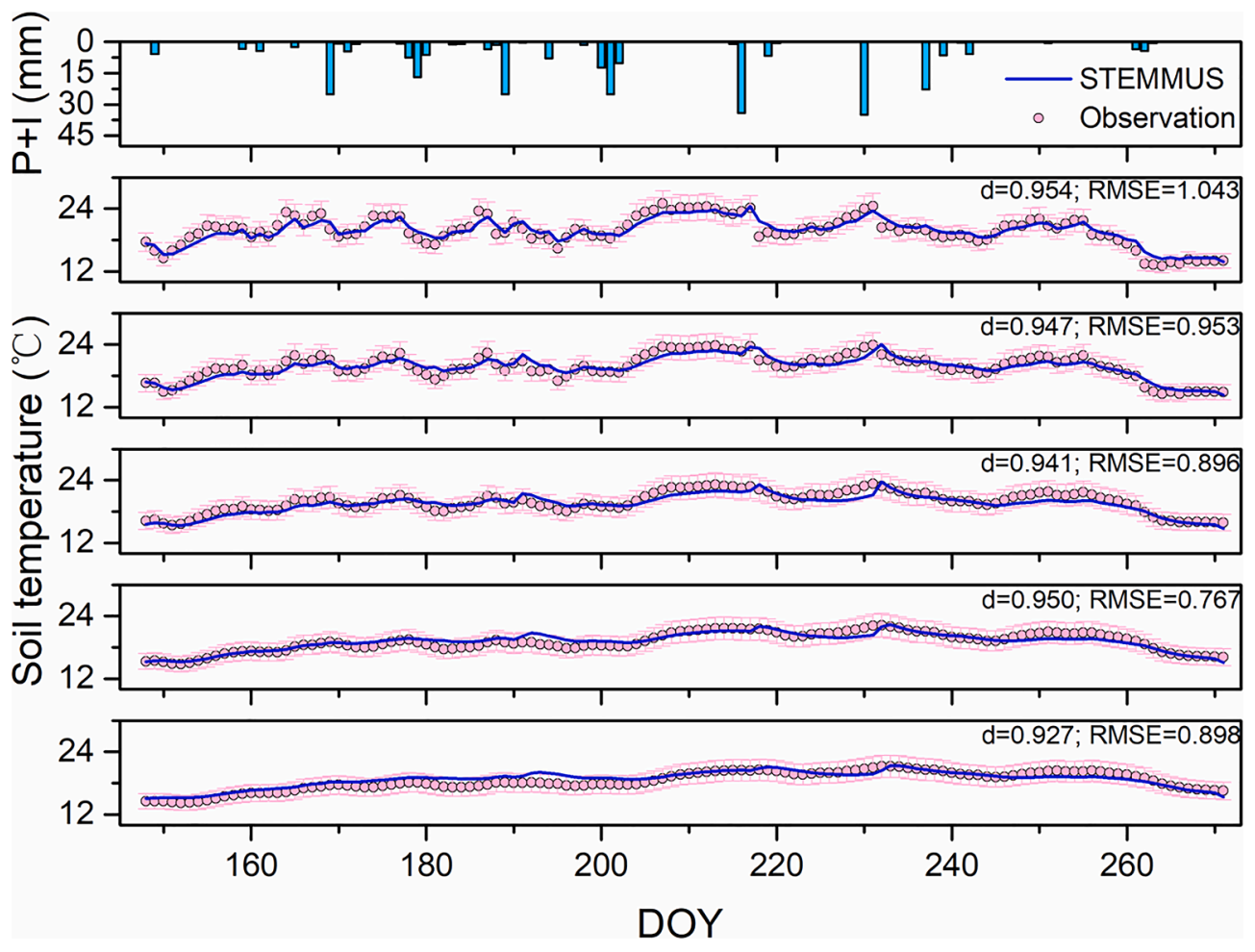

Fig. 3. Comparison of simulated (pink dots) and observed (blue line) daily soil temperature at (top to bottom): $20,40,60,80$, and $100 \mathrm{~cm}$ soil depth during the growing period. Blue bars indicate the amount of precipitation and irrigation $(\mathrm{P}+\mathrm{I})$; pink bars indicate standard errors $(\mathrm{n}=3)$. DOY is day of year. 


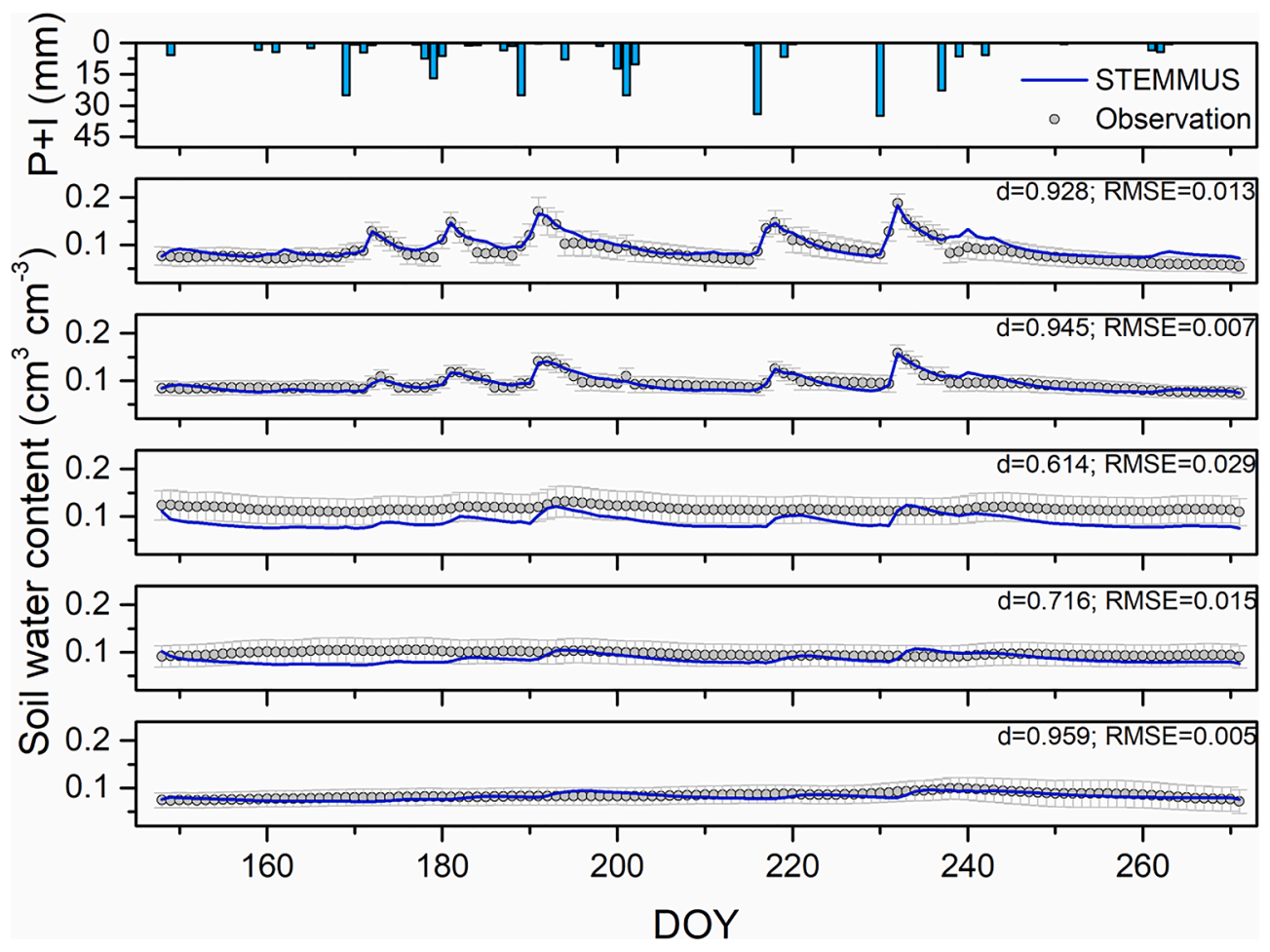

Fig. 4. Comparison of simulated (gray dots) and observed (blue line) daily soil moisture at (top to bottom): $20,40,60,80$, and $100 \mathrm{~cm}$ soil depth during the growing period. Blue bars indicate the amount of precipitation and irrigation $(\mathrm{P}+\mathrm{I})$; gray bars indicate standard errors $(\mathrm{n}=3)$. DOY is day of year.
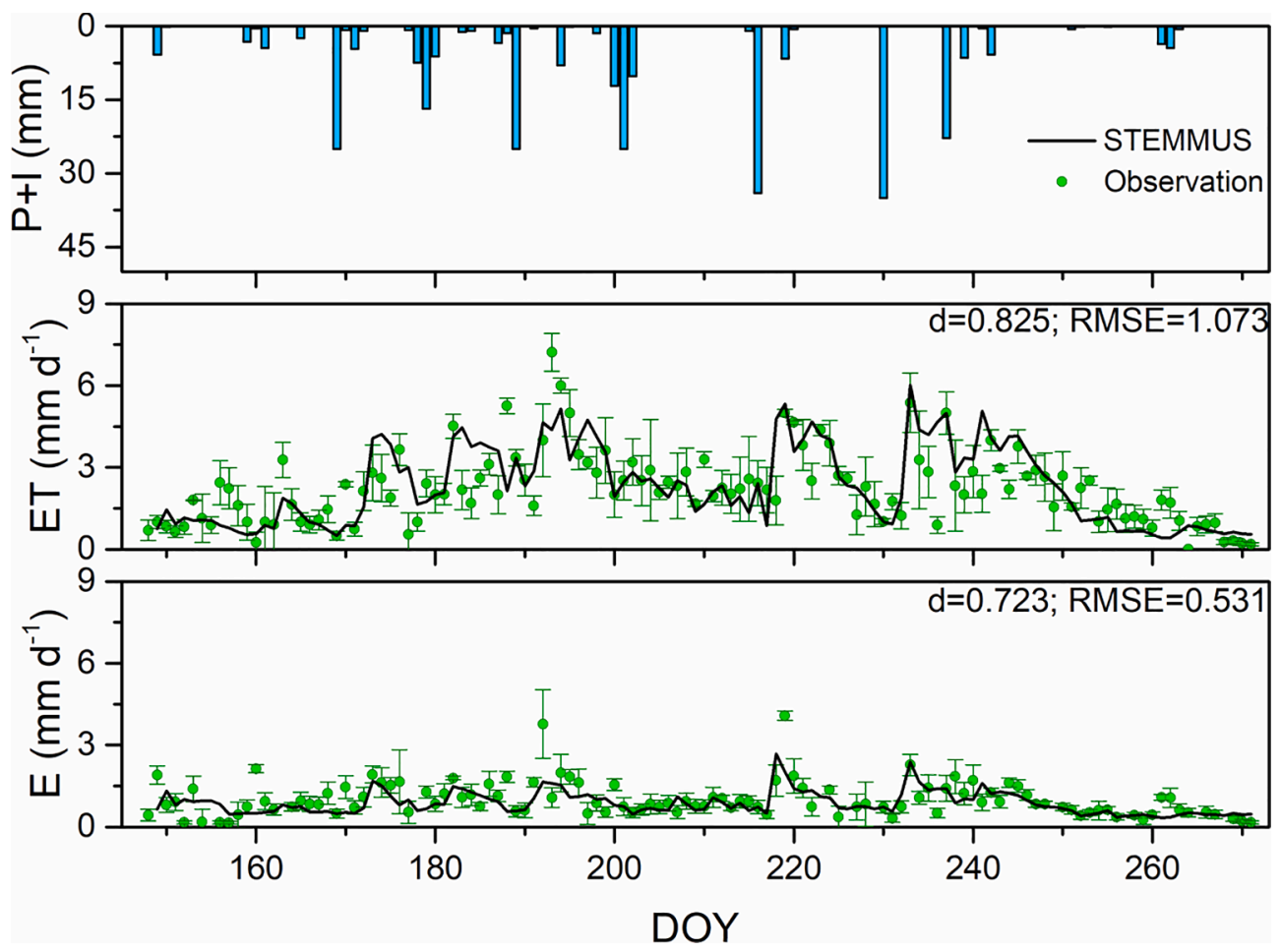

Fig. 5. Comparison of simulated (green dots) and observed (black line) daily crop evapotranspiration (ET) and soil evaporation rates (E) during the growing season. Blue bars indicate the amount of precipitation and irrigation $(\mathrm{P}+\mathrm{I})$; green bars indicate standard errors $(\mathrm{n}=2$ and 9 for ET and E, respectively). DOY is day of year.

(Zeng et al., 2011b), and therefore did not affect the two-phase flow (air-water flow) noteworthily. However, in other cases when the column was sealed (no air escape from the bottom) and the top of the column saturated or close to saturation (Zeng et al., 2011a), the air phase had a more apparent influence on the water phase flow. The relatively higher deviations between simulated and observed soil temperatures at $100 \mathrm{~cm}$ depth may be partly attributed to measurement bias associated with the sensors or the coarse-textured soils at the experimental site (Pan et al., 2015). This reflected the limited averaging of biases rather than a limitation of the models per se. Further study is 

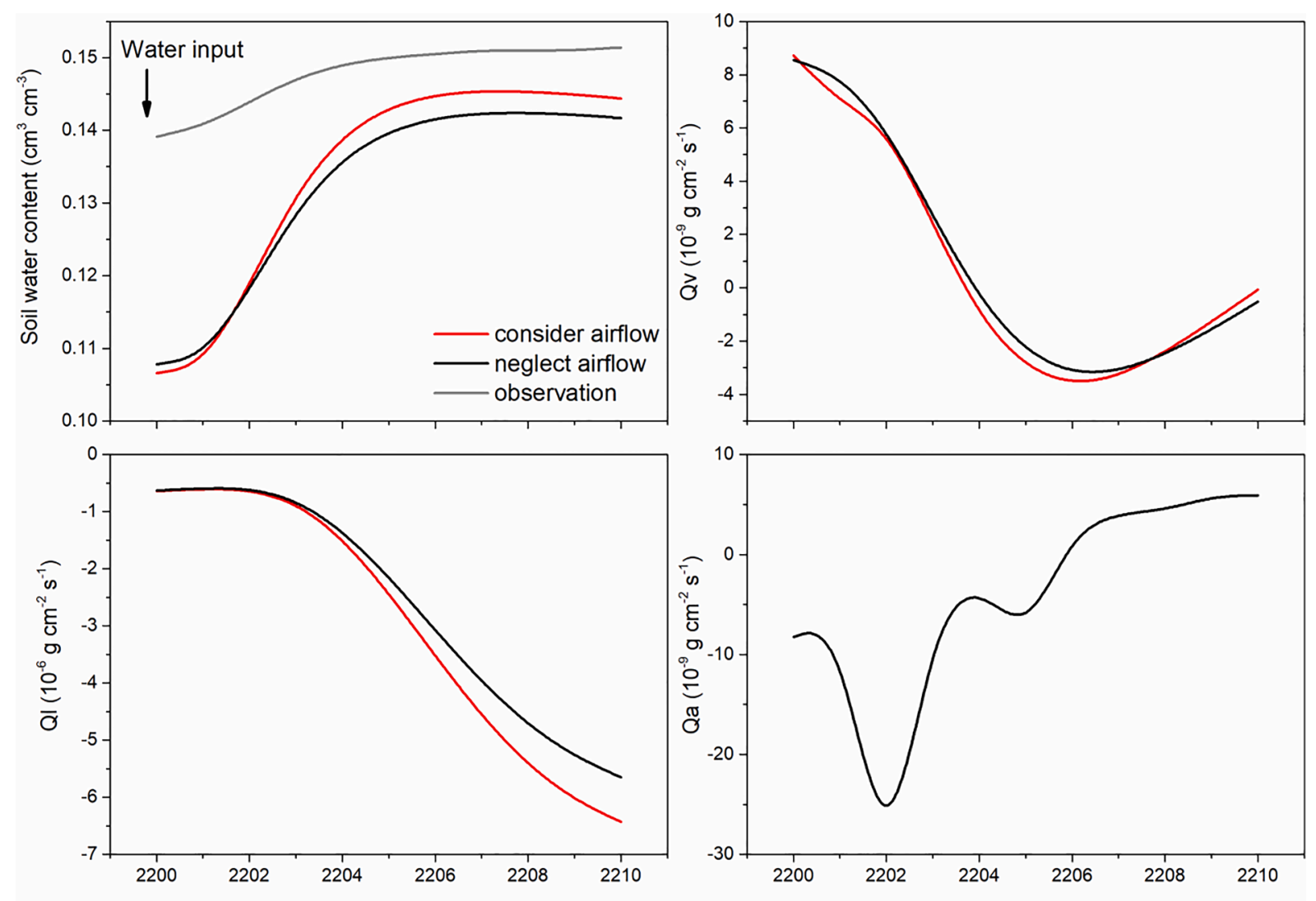

HAM

Fig. 6. Comparison of the airflow transport considering (red line) and neglecting (black line) soil moisture simulations at $20 \mathrm{~cm}$ soil layer after water input. HAM is the hour after starting the measurement, Ql is liquid water fluxes $\left(10^{-6} \mathrm{~g} \mathrm{~cm}^{-2} \mathrm{~s}^{-1}\right)$, Qv is water vapor fluxes $\left(10^{-9} \mathrm{~g} \mathrm{~cm}^{-2} \mathrm{~s}^{-1}\right)$, and Qa is soil dry air flux $\left(10^{-9} \mathrm{~g}\right.$ $\mathrm{cm}^{-2} \mathrm{~s}^{-1}$ ).

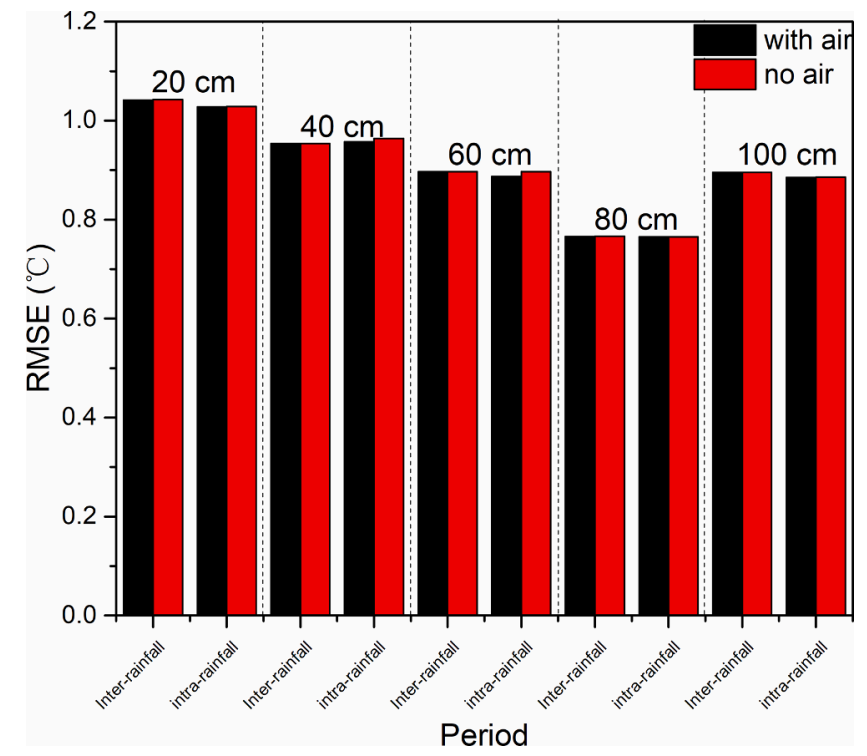

Fig. 7. Comparison of RMSE values for soil temperature simulations during inter- and intra-rainfall (or irrigation) periods at the indicated depths.

needed to conduct multi-point modeling on the TP (i.e., central and western regions) to evaluate STEMMUS performance on alpine agricultural lands.

During crop growth, the soil moisture modeling results agreed reasonably well with the observations, and the water dynamics following precipitation/irrigation events were well captured (Fig. 4). However, there were clear discrepancies at 60 and $80 \mathrm{~cm}$ soil layers. We concluded three possible reasons: firstly, this may be due to the high gravel and sand contents of the experimental soils, which can cause deviations by using general hydraulic parameter estimations according to several previous studies (Cerda, 2001; Rücknagel et al., 2013; GordilloRivero et al., 2014; Zhao et al., 2018). Secondly, the poor simulation results might be attributed to the assumption of soil profile texture uniformity in the model (Zeng et al., 2011a; Zeng et al., 2011b). As sensitivity analysis suggested (Table 2), modeling results were sensitive to the input soil hydraulic properties, thus neglecting the heterogeneity of the actual soil would inevitably lead to the reduction of simulation accuracy. A further step of model improvement is needed to consider different soil layer's characteristics. Thirdly, the soil has high contents of gravel and sand, and holes and macro - pores formed by little reptiles and decaying root matter, which could contribute to preferential flow pathways (Geiger and Durnford, 2000), and sensors installed closely to such pathways could lead to observation errors (Ramos et al., 2012; Yu et al., 2016). Incorporating airflow slightly but successfully improved 20-100 cm depth soil moisture modeling accuracy after precipitation or irrigation events happened (Fig. 8). This may be due to the consideration of airflow that retarded the water vapor transport right after precipitation/irrigation events, causing more water vapor to be condensed, and thus indirectly raised the liquid flux, making simulations closer to measurements than neglecting airflow (Fig. 6).

Crop evapotranspiration is the main method of water consumption in farmland, which binds to crop water use efficiency and yield (Wang et al., 2020). The P-M model is used worldwide to simulate crop evapotranspiration. Yu et al. (2016) embedded the P-M model into STEMMUS and successfully captured observed daily maize 


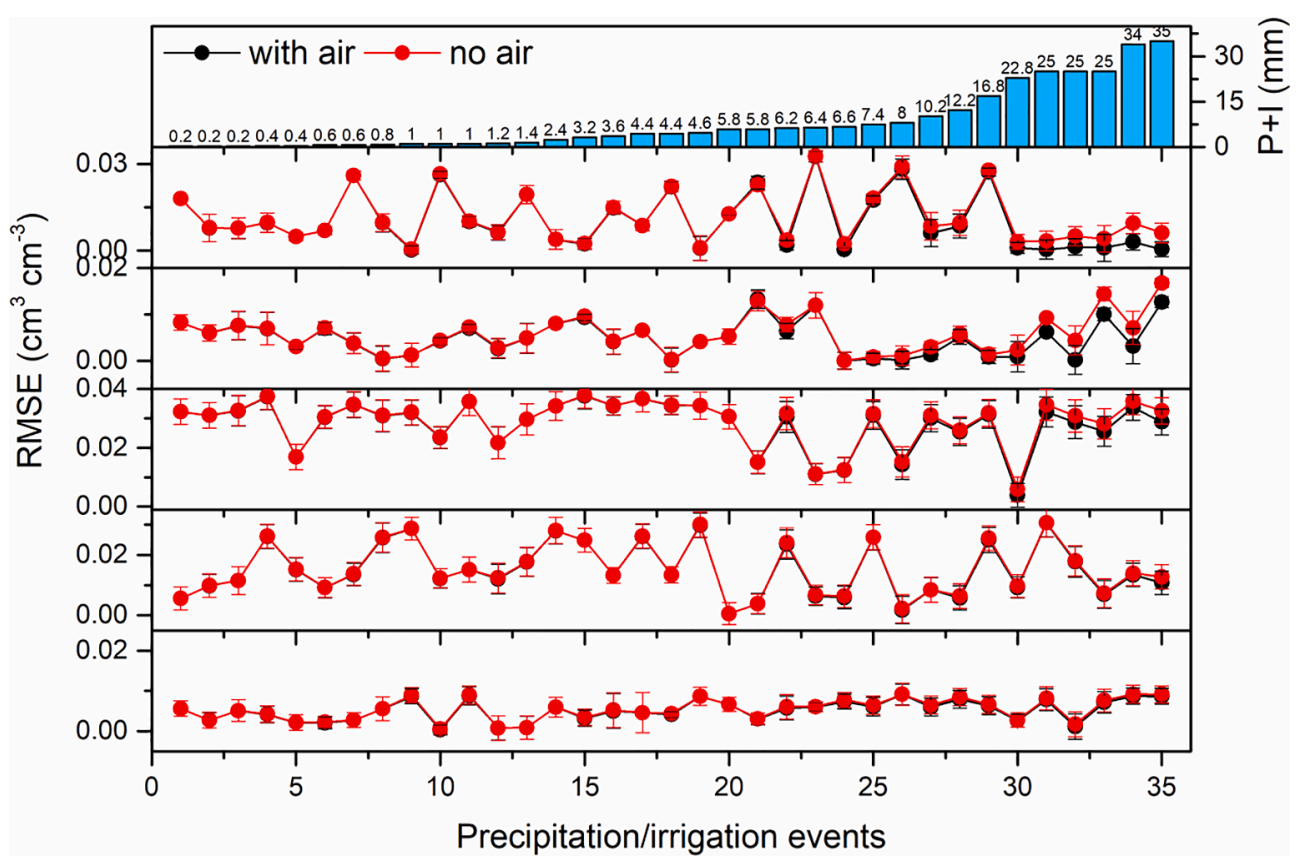

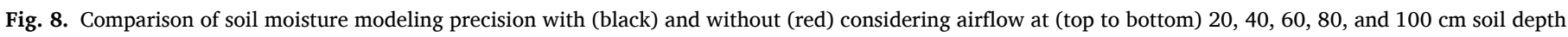
under monitored precipitation/irrigation events $(\mathrm{P}+\mathrm{I}$, blue bars). Red and black bars indicate standard errors $(\mathrm{n}=3$ ).

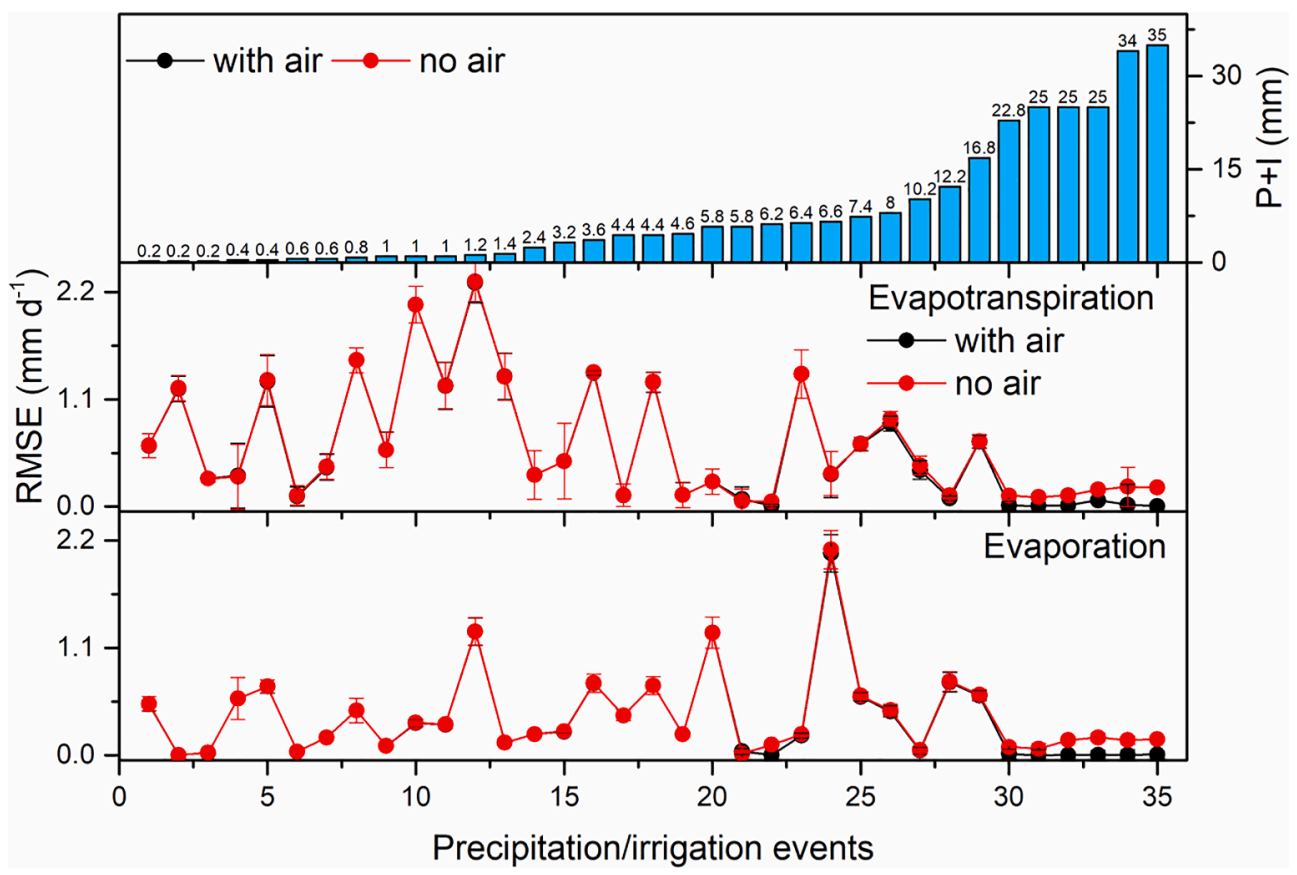

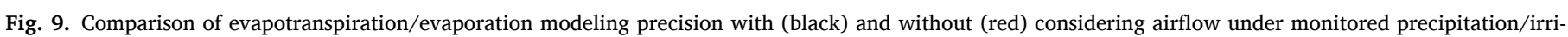
gation events ( $\mathrm{P}+\mathrm{I}$, blue bars). Red and black bars indicate standard errors $(\mathrm{n}=3)$.

evapotranspiration and soil evaporation rates. By calibrating soil and crop parameters, we also obtained the fitting modeling results for Lycium barbarum L. evapotranspiration and soil evaporation (Fig. 5). Errors in evaporation modeling may have been partly due to micro - lysimeter errors as previous studies indicated (Daamen et al., 1993; Kidron and Kronenfeld, 2017), which may arise from exclusion of roots from the lysimeters (Wei et al., 2015). Coupling soil dry airflow successfully improved the modeling precision of evapotranspiration and evaporation following precipitation or irrigation events (Fig. 9), which was attributed to the increase in modeling values, therefore reducing the discrepancies between simulated and observed values.

Vapor flow, which is dependent on soil matric potential and temperature, links soil water and heat transfer processes (Yu et al., 2020), can be significantly impacted by airflow in dry soil (Zeng et al., 2011a), and calls for a clear guidance model (Moldrup et al., 2013). In this study, however, airflow's impacts on soil water flow was not apparent which was partly ascribed to our open soil column condition, but we found heavy rainfall or irrigation would trigger the modeling differences when we considered soil airflow transport. Simulations when considering airflow had a positive correlation with increasing water inputs (Fig. 10), 

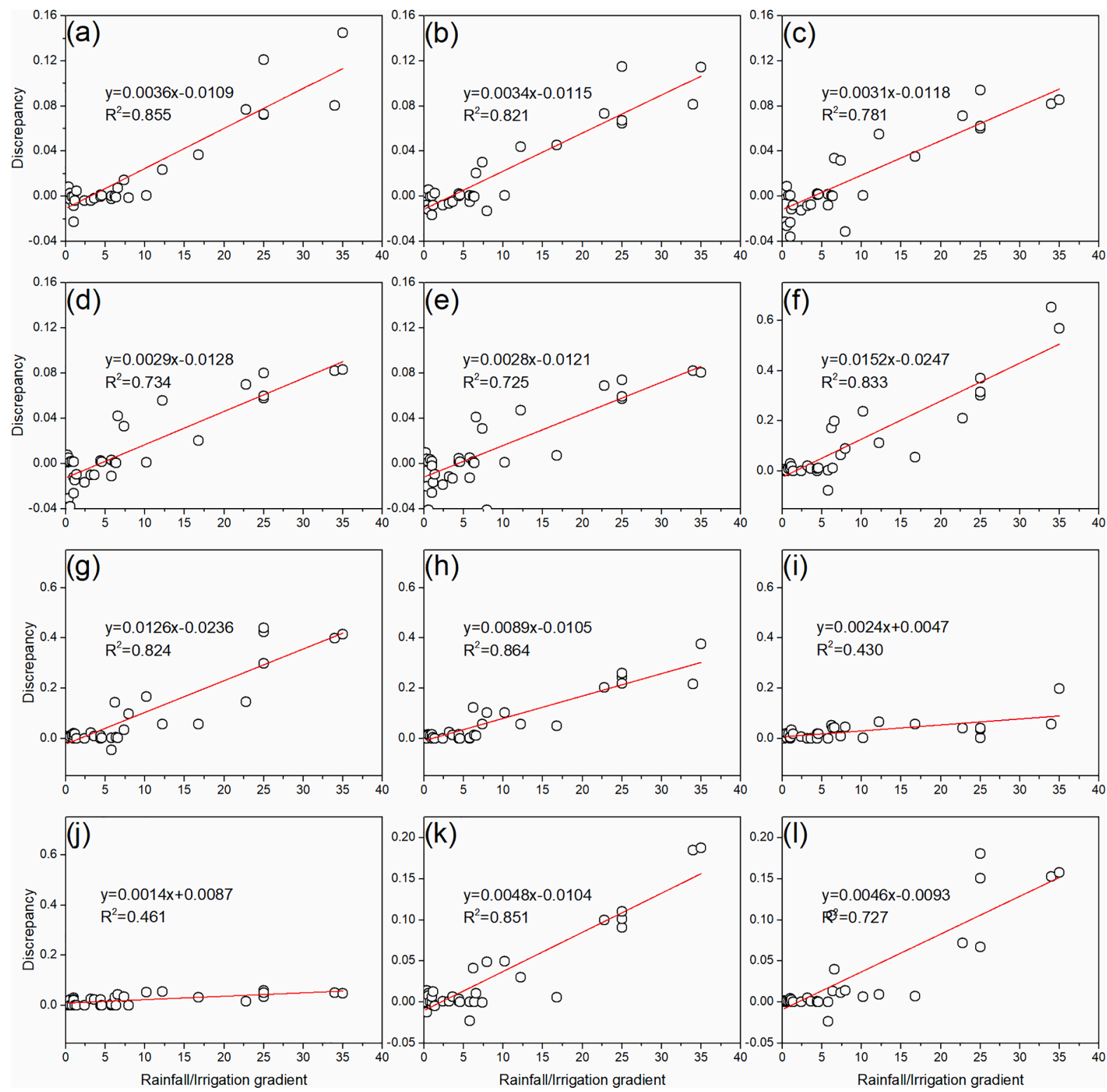

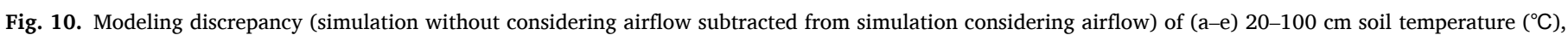
$(\mathrm{f}-\mathrm{j})$ soil moisture $(\%),(\mathrm{k})$ evapotranspiration $\left(\mathrm{mm} \mathrm{d}^{-1}\right)$, and $(\mathrm{l})$ evaporation $\left(\mathrm{mm} \mathrm{d}^{-1}\right)$ under water input (rainfall/irrigation) gradient.

which might be due to the strong variation in the soil matric potential gradient after significant precipitation/irrigation events, which subsequently affected the soil air pressure gradient at the surface, enhanced the magnitude of vapor flux by driving advective vapor transport (Zeng et al., 2011a), and indirectly increased total water flux. For soil moisture modeling (Fig. $10 \mathrm{f}-\mathrm{j}$ ), airflow behavior became weaker with increasing soil depth, which may be partially attributed to the limited precipitation and irrigation on the study site, which could only support minor water supplement when it came to deeper layers, weakened variations of soil matric potential and therefore airflow's effects. For evapotranspiration simulations (Fig. 10k), the positive relationships between airflowcoupled modeling values and water input could be partially attributed to the same patterns in evaporation simulations, as it was obtained by summing transpiration and evaporation rates. The enhanced surface evaporative flux simulations after significant precipitation/irrigation events could be partly related to the unstable wind speed at the soil surface, or the increase in soil matric potential in the topsoil layer which changes the soil air pressure gradient at the surface, promotes advective vapor transfer which is an important portion of evaporation, and further enhances the magnitude of soil evaporation flux (Zeng et al., 2011b; 2013).

\section{Conclusion}

This study demonstrated that STEMMUS can reliably describe the soil hydrothermal process and evapotranspiration dynamic in dry alpine agricultural land. Coupling soil dry airflow affected the soil hydrothermal process modeling, and the impact of considering airflow following rainfall/irrigation events was positively correlated with increasing water inputs. Considering airflow did not produce apparent differences but still successfully improved the modeling precision for soil moisture (reduction of RMSE values ranging from 0 to $95.9 \%$ ), evapotranspiration (reduction of RMSE values ranging from 0 to $97.8 \%$ ) and evaporation (reduction of RMSE values ranging from 0 to 99.3\%) following rainfall/ irrigation events. Our findings offer insight into the role of airflow in the complex soil physical processes in arid agricultural land and highlight that rainfall/irrigation inputs are a major factor affecting simulations when airflow is considered. 


\section{Declaration of Competing Interest}

The authors declare that they have no known competing financial interests or personal relationships that could have appeared to influence the work reported in this paper.

\section{Acknowledgments}

Financial and technical support from the National Key Research and Development Program of China (grant no. 2017YFC0403605), the National Natural Science Foundation of China (grant no. 41771316), Natural Science Basic Research Program of Shaanxi (2021JC-19), the Shaanxi Innovative Research Team for Key Science and Technology (grant no. 2017KCT-15), CAS 'Youth Scholar of West China' Program (grant no. XAB2018A04), and the '111' Project (grant no. B12007) is gratefully acknowledged.

\section{Appendix A. Supplementary data}

Supplementary data to this article can be found online at https://doi. org/10.1016/j.geoderma.2021.115354.

\section{References}

Ahmad, M., Chakraborty, D., Aggarwal, P., Bhattacharyya, R., Singh, R., 2018. Modelling soil water dynamics and crop water use in a soybean-wheat rotation under chisel tillage in a sandy clay loam soil. Geoderma 327, 13-24. https://doi.org/10.1016/j. geoderma.2018.04.014.

Allen, R.G., Pereira, L.S., Raes, D., Smith, M., 1998. Crop evapotranspiration-Guidelines for computing crop water requirements-FAO Irrigation and drainage paper 56. FAO, Rome, p. 300.

Arunrat, N., Pumijumnong, N., Hatano, R., 2018. Predicting local-scale impact of climate change on rice yield and soil organic carbon sequestration: A case study in Roi Et Province, Northeast Thailand. Agr. Syst. 164, 58-70. https://doi.org/10.1016/j. agsy.2018.04.001.

Bai, P., Liu, X.M., Yang, T.T., Liang, K., Liu, C.M., 2016. Evaluation of streamflow simulation results of land surface models in GLDAS on the Tibetan plateau. J. Geophys. Res-Atmos. 121 (20), 12180-12197. https://doi.org/10.1002/ 2016JD025501.

Bao, S.D., 2000. Soil agrochemical analysis. China Agriculture Press, Beijing.

Bi, H.Y., Ma, J.W., Zheng, W.J., Zeng, J.Y., 2016. Comparison of soil moisture in GLDAS model simulations and in situ observations over the Tibetan Plateau. J. Geophys. Res-Atmos. 121 (6), 2658-2678. https://doi.org/10.1002/2015JD024131.

Bittelli, M., Ventura, F., Campbell, G.S., Snyder, R.L., Gallegati, F., Pisa, P.R., 2008. Coupling of heat, water vapor, and liquid water fluxes to compute evaporation in bare soils. J. Hydrol. 362, 191-205. https://doi.org/10.1016/j.jhydrol.2008.08.014.

Buckingham, E., 1904. Contributions to our knowledge of aeration of soils. US Bur. Soils Bulletin, 25, U.S. Gov. Print. Off., Washington, D.C.

Cahill, A., Parlange, M., 1998. On water vapor transport in field soils. Water Resour. Res. 34, 731-739. https://doi.org/10.1029/97WR03756.

Cerda, A., 2001. Effects of rock fragment cover on soil infiltration, interrill runoff and erosion. Eur. J. Soil Sci. 52, 59-68. https://doi.org/10.1046/j.1365 2389.2001.00354.x.

Chung, S.O., Horton, R., 1987. Soil heat and water flow with a partial surface mulch. Water Resour. Res. 23, 2175-2186. https://doi.org/10.1029/wr023i012p02175.

d'Alpoim Guedes, J., 2018. Did foragers adopt farming? A perspective from the margins of the Tibetan Plateau. Quat. Int. 489, 91-100. https://doi.org/10.1016/j. quaint.2016.12.010.

d'Alpoim Guedes, J.A., Lu, H., Hein, A.M., Schmidt, A.H., 2015. Early evidence for the use of wheat and barley as staple crops on the margins of the Tibetan Plateau. Proc. Natl. Acad. Sci. U. S. A. 112, 5625-5630. https://doi.org/10.1073/ pnas.1423708112.

d'Alpoim Guedes, J., Lu, H., Li, Y., Spengler, R.N., Wu, X., Aldenderfer, M.S., 2013. Moving agriculture onto the Tibetan plateau: the archaeobotanical evidence. Archaeol. Anthrop. Sci. 6, 255-269. https://doi.org/10.1007/s12520-013-0153-4.

Daamen, C., Simmonds, L., Wallace, J., Laryea, K., Sivakumar, M., 1993. Use of microlysimeters to measure evaporation from sandy soils. Agr. Forest Meteorol. 65, 159-173. https://doi.org/10.1016/0168-1923(93)90002-Y.

de Rooij, G.H., 2010. Comments on "Improving the Numerical Simulation of Soil Moisture-Based Richards Equation for Land Models with a Deep or Shallow Water Table". J. Hydrometeorol. 11, 1044-1050. https://doi.org/10.1175/ 2010jhm1189.1.

De Vries, D.A., 1958. Simultaneous transfer of heat and moisture in porous media. Trans. Am. Geophys. Union 39, 909-916. https://doi.org/10.1029/TR039i005p00909.

De Vries, D.A., 1963. Thermal properties of soils, Physics of Plant Environment. NorthHolland Publishing Company, Amsterdam, pp. 210-235.

Di Prima, S., Castellini, M., Abou Najm, M.R., Stewart, R.D., Angulo-Jaramillo, R., Winiarski, T., Lassabatere, L., 2019. Experimental assessment of a new comprehensive model for single ring infiltration data. J. Hydrol. 573, 937-951. https://doi.org/10.1016/j.jhydrol.2019.03.077.

Ding, J., Wang, T., Piao, S., Smith, P., Zhang, G., Yan, Z., Ren, S., Liu, D., Wang, S., Chen, S., Dai, F., He, J., Li, Y., Liu, Y., Mao, J., Arain, A., Tian, H., Shi, X., Yang, Y., Zeng, N., Zhao, L., 2019. The paleoclimatic footprint in the soil carbon stock of the Tibetan permafrost region. Nat. Commun. 10, 4195. https://doi.org/10.1038/ s41467-019-12214-5.

Fan, K.K., Zhang, Q., Singh, V.P., Sun, P., Song, C.Q., Zhu, X.D., Yu, H.Q., Shen, Z.X., 2019. Spatiotemporal impact of soil moisture on air temperature across the Tibet Plateau. Sci. Total Environ. 649, 1338-1348. https://doi.org/10.1016/j. scitotenv.2018.08.399.

Feddes, R.A., Kowalik, P.J., Zaradny, H., 1978. Simulation of field water use and crop yield. In: Centre for Agricultural Publishing and Documentation. Wageningen, the Netherlands, pp. 194-209.

Flerchinger, G.N., Saxton, K.E., 1989. Simultaneous heat and water model of a freezing snow-residue-soil system. I. Theory and development. T. ASAE 32, 565-571.

Gao, B., Farnsworth, J., Smits, K.M., 2020. Evaporation from undulating soil surfaces under turbulent airflow through numerical and experimental approaches. Vadose Zone J. 19 https://doi.org/10.1002/vzj2.20038.

Garcia Gonzalez, R., Verhoef, A., Luigi Vidale, P., Braud, I., 2012. Incorporation of water vapor transfer in the JULES land surface model: Implications for key soil variables and land surface fluxes. Water Resour. Res. 48 https://doi.org/10.1029/ 2011 wr011811.

Geiger, S., Durnford, D., 2000. Infiltration in homogeneous sands and a mechanistic model of unstable flow. Soil Sci. Soc. Am. J. 64 (460-469), 2000. https://doi.org/ 10.2136/sssaj2000.642460x.

GordilloRivero, Á.J., GarcíaMoreno, J., Jordán, A., Zavala, L.M., 2014. Effects of rock fragments on water dynamics in a fire-affected soil. Egu General Assembly Conference.

Grifoll, J., Gastó, J.M., Cohen, Y., 2005. Non-isothermal soil water transport and evaporation. Adv. Water Resour. 28, 1254-1266. https://doi.org/10.1016/j. advwatres.2005.04.008.

Harris, R.B., 2010. Rangeland degradation on the Qinghai-Tibetan plateau: A review of the evidence of its magnitude and causes. J. Arid Environ. 74, 1-12. https://doi.org/ 10.1016/j.jaridenv.2009.06.014.

Hou, L., Hu, B. X., Li, H., Wan, L., 2018. Potential impacts of climate variation on potato field evapotranspiration: Field experiment and numerical simulation of potato water use in an arid site. J. Geophys. Res-Atmos. 123. 10,202-210,214, 10.1029/ 2018jd028841.

Hu, G., Zhao, L., Li, R., Wu, T., Wu, X., Pang, Q., Xiao, Y., Qiao, Y., Shi, J., 2015. Modeling hydrothermal transfer processes in permafrost regions of Qinghai-Tibet Plateau in China. Chin. Geogra. Sci. 25, 713-727. https://doi.org/10.1007/s11769015-0733-6.

Hu, W., Wang, Y., Li, H., Huang, M., Hou, M., Li, Z., She, D., Si, B., 2019. Dominant role of climate in determining spatio-temporal distribution of potential groundwater recharge at a regional scale. J. Hydrol. 578, 1-13. https://doi.org/10.1016/j. jhydrol.2019.124042.

Kacimov, A. R., Obnosov, Y. V., Šimůnek, J., 2019. Minimizing evaporation by optimal layering of topsoil: Revisiting Ovsinsky's smart mulching-tillage technology via Gardner-Warrick's unsaturated analytical model and HYDRUS. Water Resour. Res. 10.1029/2018wr024025.

Kader, M.A., Nakamura, K., Senge, M., Mojid, M.A., Kawashima, S., 2019. Numerical simulation of water- and heat-flow regimes of mulched soil in rain-fed soybean field in central Japan. Soil Till. Res. 191, 142-155. https://doi.org/10.1016/j. still.2019.04.006.

Kidron, G.J., Kronenfeld, R., 2017. Assessing the effect of micro-lysimeters on NRWI: Do micro-lysimeters adequately represent the water input of natural soil? J. Hydrol. 548, 382-390. https://doi.org/10.1016/j.jhydrol.2017.03.005.

Linden, D.R., Dixon, R.M., 1975. Water table position as affected by soil air pressure. Water Resour. Res. 11 (1), 139-143. https://doi.org/10.1029/WR011I001P00139.

Liu, M., Xu, X., Sun, A., Luo, W., Wang, K., 2018a. Why do karst catchments exhibit higher sensitivity to climate change? Evidence from a modified Budyko model. Adv. Water Resour. 122, 238-250. https://doi.org/10.1016/j.advwatres.2018.10.013.

Liu, S., Zamanian, K., Schleuss, P.M., Zarebanadkouki, M., Kuzyakov, Y., 2018b. Degradation of Tibetan grasslands: Consequences for carbon and nutrient cycles. Agr. Ecosyst. Environ. 252, 93-104. https://doi.org/10.1016/j.agee.2017.10.011.

Luo, D.L., Jin, H.J., Bense, V.F., Jin, X.Y., Li, X.Y., 2020. Hydrothermal processes of nearsurface warm permafrost in response to strong precipitation events in the Headwater Area of the Yellow River. Tibetan Plateau. Geoderma 376, 114531. https://doi.org/ 10.1016/j.geoderma.2020.114531.

Luo, Z., Kong, J., Shen, C., Lu, C., Hua, G., Zhao, Z., Zhao, H., Li, L., 2019. Evaluation and application of the modified van Genuchten function for unsaturated porous media. J. Hydrol. 571, 279-287. https://doi.org/10.1016/j.jhydrol.2019.01.051.

Martínez, I., Chervet, A., Weisskopf, P., Sturny, W.G., Rek, J., Keller, T., 2016. Two decades of no-till in the Oberacker long-term field experiment: Part II. Soil porosity and gas transport parameters. Soil Till. Res. 163, 130-140. https://doi.org/10.1016/ j.still.2016.05.020.

Massari, C., Brocca, L., Moramarco, T., Tramblay, Y., Lescot, J.F.D., 2014. Potential of soil moisture observations in flood modelling: Estimating initial conditions and correcting rainfall. Adv. Water Resour. 74, 44-53. https://doi.org/10.1016/j. advwatres.2014.08.004.

Miehe, G., Schleuss, P.M., Seeber, E., Babel, W., Biermann, T., Braendle, M., Chen, F., Coners, H., Foken, T., Gerken, T., Graf, H.F., Guggenberger, G., Hafner, S., Holzapfel, M., Ingrisch, J., Kuzyakov, Y., Lai, Z., Lehnert, L., Leuschner, C., Li, X., Liu, J., Liu, S., Ma, Y., Miehe, S., Mosbrugger, V., Noltie, H.J., Schmidt, J., Spielvogel, S., Unteregelsbacher, S., Wang, Y., Willinghofer, S., Xu, X., Yang, Y., 
Zhang, S., Opgenoorth, L., Wesche, K., 2019. The Kobresia pygmaea ecosystem of the Tibetan highlands - Origin, functioning and degradation of the world's largest pastoral alpine ecosystem: Kobresia pastures of Tibet. Sci. Total Environ. 648, 754-771. https://doi.org/10.1016/j.scitotenv.2018.08.164.

Milly, P.C.D., 1982. Moisture and heat transport in hysteretic, inhomogeneous porous media: A matric head-based formulation and a numerical model. Water Resour. Res. 18, 489-498. https://doi.org/10.1029/WR018i003p00489.

Moldrup, P., Chamindu, D.T.K., Hamamoto, S., Komatsu, T., Kawamoto, K., Rolston, D. E., de Jonge, L.W., 2013. Structure-dependent water-induced linear reduction model for predicting gas diffusivity and tortuosity in repacked and intact soil. Vadose Zone J. 12, 1-11. https://doi.org/10.2136/vzj2013.01.0026.

Olivella, S., Gens, A., 2000. Vapour transport in low permeability unsaturated soils with capillary effects. Transp. Porous Media 40 (2), 219-241. https://doi.org/10.1023/A: 1006749505937.

Pan, C., Zhu, B., Gao, J., Kang, H., Zhu, T., 2018. Quantitative identification of moisture sources over the Tibetan Plateau and the relationship between thermal forcing and moisture transport. Clim. Dynam. 52, 181-196. https://doi.org/10.1007/s00382 018-4130-6.

Pan, Y., Lyu, S., Li, S., Gao, Y., Meng, X., Ao, Y., Wang, S., 2015. Simulating the role of gravel in freeze-thaw process on the Qinghai-Tibet Plateau. Theor. Appl. Climatol. 127, 1011-1022. https://doi.org/10.1007/s00704-015-1684-7.

Parlange, M., Cahill, A., Nielsen, D., Hopmans, J., Wendroth, O., 1998. Review of heat and water movement in field soils. Soil Till. Res. 47, 5-10. https://doi.org/10.1016/ S0167-1987(98)00066-X.

Prunty, L., Bell, J., 2007. Infiltration rate vs. gas composition and pressure in soil columns. Soil Sci. Soc. Am. J. 71, 1473-1475. https://doi.org/10.2136/ sssaj2007.0072N.

Qiu, J., 2008. The third pole. Nature 454, 393-396. https://doi.org/10.1038/454393a.

Ramos, T.B., Šimůnek, J., Gonçalves, M.C., Martins, J.C., Prazeres, A., Pereira, L.S., 2012 Two-dimensional modeling of water and nitrogen fate from sweet sorghum irrigated with fresh and blended saline waters. Agr. Water Manage. 111, 87-104. https://doi. org/10.1016/j.agwat.2012.05.007.

Ren, D., Xu, X., Hao, Y., Huang, G., 2016. Modeling and assessing field irrigation water use in a canal system of Hetao, upper Yellow River basin: Application to maize, sunflower and watermelon. J. Hydrol. 532, 122-139. https://doi.org/10.1016/j jhydrol.2015.11.040.

Ren, Z., Niu, D., Ma, P., Wang, Y., Fu, H., Elser, J.J., 2019. Cascading influences of grassland degradation on nutrient limitation in a high mountain lake and its inflow streams. Ecology 100, 1-13. https://doi.org/10.1002/ecy.2755.

Rücknagel, J., Götze, P., Hofmann, B., Christen, O., Marschall, K., 2013. The influence of soil gravel content on compaction behaviour and pre-compression stress. Geoderma 209-210, 226-232. https://doi.org/10.1016/j.geoderma.2013.05.030.

Sadeghi, M., Tuller, M., Warrick, A.W., Babaeian, E., Parajuli, K., Gohardoust, M.R., Jones, S.B., 2019. An analytical model for estimation of land surface net water flux from near-surface soil moisture observations. J. Hydrol. 570, 26-37. https://doi.org/ 10.1016/j.jhydrol.2018.12.038.

Saito, H., Šimůnek, J., Mohanty, B.P., 2006. Numerical analysis of coupled water, vapor, and heat transport in the vadose zone. Vadose Zone J. 5 https://doi.org/10.2136/ vzj2006.0007.

Scanlon, B., Milly, P., 1994. Water and heat fluxes in desert soils.2. Numerical simulations. Water Resour. Res. 30, 721-733. https://doi.org/10.1029/93WR03252.

Schrefler, B.A., Zhan, X., 1993. A fully coupled model for water flow and airflow in deformable porous media. Water Resour. Res. 29, 155-167. https://doi.org/ $10.1029 / 92$ wr01737.

Šimůnek, J., van Genuchten, M.T., 2008. Modeling nonequilibrium flow and transport processes using HYDRUS. Vadose Zone J. 7 https://doi.org/10.2136/vzj2007.0074.

Tahiri, A.Z., Anyoji, H., Yasuda, H., 2006. Fixed and variable light extinction coefficients for estimating plant transpiration and soil evaporation under irrigated maize. Agr. Water Manage. 84, 186-192. https://doi.org/10.1016/j.agwat.2006.02.002.

Thomas, H., Sansom, M., 1995. Fully coupled analysis of heat, moisture, and air transfer in unsaturated soil. J. Eng. Mech-ASCE 121, 392-405. https://doi.org/10.1061/ (ASCE)0733-9399(1995)121:3(392).

Touma, J., Vauclin, M., 1986. Experimental and numerical analysis of two-phase infiltration in a partially saturated soil. Transport Porous Med. 1, 27-55. https://doi. org /10.1007/BF01036524.

Ugbaje, S.U., Reuter, H.I., 2013. Functional digital soil mapping for the prediction of available water capacity in Nigeria using legacy data. Vadose Zone J. 12 https://doi org/10.2136/vzj2013.07.0140.

Van De Griend, A.A., Owe, M., 1994. Bare soil surface resistance to evaporation by vapor diffusion under semiarid conditions. Water Resour. Res. 30, 181-188. https://doi. org/10.1029/93WR02747.

Van Genuchten, M.T., 1980. A closed-form equation for predicting the hydraulic conductivity of unsaturated soils. Soil Sci. Soc. Am. J. 44, 892-898. https://doi.org/ 10.2136/sssaj1980.03615995004400050002x.

Vereecken, H., Weynants, M., Javaux, M., Pachepsky, Y., Schaap, M. G., Genuchten, M. T. v., 2010. Using pedotransfer functions to estimate the van Genuchten-Mualem soil hydraulic properties: A review. Vadose Zone J. 9. 10.2136/vzj2010.0045.

Wang, G.J., Hagan, D.F.T., Lou, D., Chen, T.X., 2016. Evaluation of soil moisture derived from FY3B microwave brightness temperature over the Tibetan Plateau. Remote Sens. Lett. 7 (9), 817-826. https://doi.org/10.1080/2150704X.2016.1192303.
Wang, J.X., Gao, X.D., Zhou, Y.Q., Wu, P.T., Zhao, X.N., 2020. Impact of conservation practices on soil hydrothermal properties and crop water use efficiency in a dry agricultural region of the Tibetan plateau. Soil Till. Res. 200, 104619 https://doi. org/10.1016/j.still.2020.104619.

Wang, Z., Feyen, J., van Genuchten, M.T., Nielsen, D.R., 1998. Air entrapment effects on infiltration rate and flow instability. Water Resour. Res. 34 (2), 213-222. https:// doi.org/10.1029/97WR02804.

Weber, T.K.D., Iden, S.C., Durner, W., 2017. A pore-size classification for peat bogs derived from unsaturated hydraulic properties. Hydrol. Earth Syst. Sc. 21, 6185-6200. https://doi.org/10.5194/hess-21-6185-2017.

Wei, Z., Paredes, P., Liu, Y., Chi, W.W., Pereira, L.S., 2015. Modelling transpiration, soil evaporation and yield prediction of soybean in North China Plain. Agr. Water Manage. 147, 43-53. https://doi.org/10.1016/j.agwat.2014.05.004.

Wicky, J., Hauck, C., 2017. Numerical modelling of convective heat transport by air flow in permafrost talus slopes. Cryosphere 11, 1311-1325. https://doi.org/10.5194/tc11-1311-2017.

Xue, X., Xu, M.H., You, Q.G., Peng, F., 2014. Influence of Experimental Warming on Heat and Water Fluxes of Alpine Meadows in the Qinghai-Tibet Plateau. Arct. Antarct. Alp. Res. 46 (2), 441-458. https://doi.org/10.1657/1938-4246-46.2.441.

Yamasaki, T., Imoto, H., Hamamoto, S., Nishimura, T., 2017. Determination of the role of entrapped air in water flow in a closed soil pipe using a laboratory experiment. Hydrol. Process. 31, 3740-3749. https://doi.org/10.1002/hyp.11302.

Yang, B., Zhao, X. N., Gao, X. D., Pan, D. L., Huo, G. P., Ye, M. T., 2021. Simulation of Water and Heat Coupling Process in Loess Based on Dry Air-flow Mechanism - A Case Study of an Apple Orchard on Mountain. Acta Pedologica Sinica. (In Chinese with English abstract).

Yang, K., Ye, B.S., Zhou, D.G., Wu, B.Y., Foken, T., Qin, J., Zhou, Z.Y., 2011. Response of hydrological cycle to recent climate changes in the Tibetan Plateau. Clim. Change 109 (3-4), 517-534. https://doi.org/10.1007/s10584-011-0099-4.

Yang, K., Zhu, L., Chen, Y.Y., Zhao, L., Qin, J., Lu, H., Tang, W.J., Han, M.L., Ding, B.H., Fang, N., 2016. Land surface model calibration through microwave data assimilation for improving soil moisture simulations. J. Hydrol. 533, 266-276. https://doi.org/ 10.1016/j.jhydrol.2015.12.018.

Yang, K., Wang, C.H., 2019. Water storage effect of soil freeze-thaw process and its impacts on soil hydro-thermal regime variations. Agr. Forest Meteorol. 265, 280-294. https://doi.org/10.1016/j.agrformet.2018.11.011.

Yao, Z., Zhao, C., Yang, K., Liu, W., Li, Y., You, J., Xiao, J., 2016. Alpine grassland degradation in the Qilian Mountains, China - A case study in Damaying Grassland. Catena 137, 494-500. https://doi.org/10.1016/j.catena.2015.09.021.

Yu, L., Zeng, Y., Su, Z., Cai, H., Zheng, Z., 2016. The effect of different evapotranspiration methods on portraying soil water dynamics and ET partitioning in a semi-arid environment in Northwest China. Hydrol. Earth Syst. Sc. 20, 975-990. https://doi. org/10.5194/hess-20-975-2016.

Yu, L., Zeng, Y., Wen, J., Su, Z., 2018. Liquid-vapor-air flow in the frozen soil. J. Geophys. Res-Atmos. https://doi.org/10.1029/2018jd028502.

Yu, L., Zeng, Y., Su, Z., 2020. Understanding the mass, momentum, and energy transfer in the frozen soil with three levels of model complexities. Hydrol. Earth Syst. Sc. 24 (10), 4813-4830. https://doi.org/10.5194/hess-24-4813-2020.

Zeng, Y., Su, Z., Wan, L., Yang, Z., Zhang, T., Tian, H., Shi, X., Wang, X., Cao, W., 2009. Diurnal pattern of the drying front in desert and its application for determining the effective infiltration. Hydrol. Earth Syst. Sc. 13, 703-714. https://doi.org/10.5194/ hess-13-703-2009.

Zeng, Y., Su, Z., Wan, L., Wen, J., 2011a. Numerical analysis of air-water-heat flow in unsaturated soil: Is it necessary to consider airflow in land surface models? J. Geophys. Res-Atmos. 116 https://doi.org/10.1029/2011jd015835.

Zeng, Y., Su, Z., Wan, L., Wen, J., 2011b. A simulation analysis of the advective effect on evaporation using a two-phase heat and mass flow model. Water Resour. Res. 47 https://doi.org/10.1029/2011wr010701.

Zeng, Y., Su, Z., 2013. Reply to comment by Binayak P. Mohanty and Zhenlei Yang on "A simulation analysis of the advective effect on evaporation using a two-phase heat and mass flow model”. Water Resour. Res. 49, 7836-7840. https://doi.org/10.1002/ 2013 wr013764.

Zhang, G., Dong, J., Zhou, C., Xu, X., Wang, M., Ouyang, H., Xiao, X., 2013. Increasing cropping intensity in response to climate warming in Tibetan Plateau. China. Field Crop. Res. 142, 36-46. https://doi.org/10.1016/j.fcr.2012.11.021.

Zhang, Q., Fan, K.K., Singh, V.P., Song, C.Q., Xu, C.Y., Sun, P., 2019. Is HimalayanTibetan Plateau "drying"? Historical estimations and future trends of surface soil moisture. Sci. Total Environ. 658, 374-384. https://doi.org/10.1016/j. scitotenv.2018.12.209.

Zhang, T., Zhan, X., Kang, Y., Wan, S., Feng, H., 2016. Improvements of soil salt characteristics and nutrient status in an impermeable saline-sodic soil reclaimed with an improved drip irrigation while ridge planting Lycium barbarum L. J. Soil. Sediment. 17, 1126-1139. https://doi.org/10.1007/s11368-016-1600-5.

Zhao, H., Zeng, Y., Lv, S., Su, Z., 2018. Analysis of soil hydraulic and thermal properties for land surface modeling over the Tibetan Plateau. Earth Syst. Sci. Data 10, 1031-1061. https://doi.org/10.5194/essd-10-1031-2018.

Zheng, D.H., Wang, X., van der Velde, R., Ferrazzoli, P., Wen, J., Wang, Z.L., Schwank, M., Colliander, A., Bindlish, R., Su, Z.B., 2018. Impact of surface roughness, vegetation opacity and soil permittivity on L-band microwave emission and soil moisture retrieval in the third pole environment. Remote Sens. Environ. 209, 633-647. https://doi.org/10.1016/j.rse.2018.03.011. 